\title{
Calibrating the glycerol dialkyl glycerol tetraether temperature signal in speleothems
}

\author{
Alison J. Blyth ${ }^{\mathrm{a}, *}$, Stefan Schouten ${ }^{\mathrm{b}, \mathrm{c}}$ \\ ${ }^{a}$ Department of Earth \& Environmental Sciences, The Open University, Walton Hall, Milton Keynes, MK7 6AA, UK \\ ${ }^{\mathrm{b}}$ Department of Marine Organic Biogeochemistry, NIOZ Royal Netherlands Institute for Sea Research, 't Horntje, Texel, The Netherlands \\ ${ }^{\mathrm{c}}$ Department of Earth Sciences, Faculty of Geosciences, Utrecht University, Utrecht, The Netherlands
}

Received 8 June 2012; accepted in revised form 5 February 2013; available online 16 February 2013

\begin{abstract}
Palaeotemperature proxies based on glycerol dialkyl glycerol tetraethers (GDGTs) lipids have been established for marine and lacustrine environments, but there has been relatively little study of their application in speleothems. In this study we analyse the GDGT content of 33 speleothem samples from 16 different sites around the globe, and test whether proxies based on isoprenoid tetraethers $\left(\mathrm{TEX}_{86}\right)$ or branched tetraethers $(\mathrm{MBT} / \mathrm{CBT})$ are correlated with measured surface and cave mean annual air temperature (MAT). The results show that the $\mathrm{TEX}_{86}$ has a strong relationship with measured temperature $\left(r^{2}=0.78\right.$, standard error of the estimate $2.3{ }^{\circ} \mathrm{C}$, when calibrated with surface MAT). Furthermore, the MBT/CBT also showed a significant relationship with temperature $\left(r^{2}=0.73\right.$, standard error of the estimate $2.7^{\circ} \mathrm{C}$, when calibrated with surface MAT). Some issues remain requiring future work, in particular the development of a larger calibration sample set with measured cave temperature data, and the investigation of controls other than temperature on GDGT distribution, but overall the results indicate that GDGT based proxies derived from speleothems may be highly viable new methods for reconstructing continental palaeotemperatures.
\end{abstract}

(c) 2013 Elsevier Ltd. All rights reserved.

\section{INTRODUCTION}

The recovery of both global and regional palaeotemperature records is an issue of vital importance in palaeoclimatic research, being central to both our understanding of past environmental change, and providing the basis for the development of models for future climate. A number of palaeotemperature proxies have been developed, but these have tended to focus on ice-cores and oceanic sediments (e.g. Dansgaard et al., 1993; Müller et al., 1998; Petit et al., 1999; Elderfield and Ganssen, 2000; Johnsen et al., 2001) with less work focused on the development of an

\footnotetext{
* Corresponding author. Current address: WA-OIGC, Chemistry and Resources Precinct, Curtin University, GPO Box U1987, Perth, WA 6845, Australia. Tel.: +61 89266 9388; fax: +61 89266 2300.

E-mail address: Alison.Blyth@curtin.edu.au (A.J. Blyth).
}

independent palaeotemperature measure for continental regions.

Stalagmites are ideal archives for terrestrial climate proxies as they form in incremental laminations, are easy to date precisely via uranium series analysis, and collect a wide range of chemical signals transported by the feed drip-water, including stable isotopes, trace elements, and organic matter. To date, attempts to recover temperature proxies from stalagmites have focused on stable isotopes in the calcite matrix (e.g. Gascoyne et al., 1980; Talma and Vogel, 1992; Mangini et al., 2005), clumped isotope thermometry of the calcite (Affek et al., 2008; Meckler et al., 2009), or isotopic or noble gas analysis of fluid inclusions (Schwarcz and Harmon, 1976; Genty et al., 2002; van Breukelen et al., 2008; Scheidegger et al., 2010). Analysis of $\delta^{18} \mathrm{O}$ in stalagmite calcite is now largely recognised as being an unreliable proxy for temperature due to the large number of confounding factors that affect the signal (McDermott, 2004). Clumped isotope analysis shows more 
promise, with the signal being an internal function of the carbonate mineral independent of the isotopic composition of the water (Affek et al., 2008). However, it was found that there is disequilibrium in the clumped isotopes due to $\mathrm{ki}$ netic isotopic fractionation, leading to temperature underestimates (Daëron et al., 2011).

The development of an organic temperature proxy in stalagmites would provide a measure of temperature completely independent of the isotopic system. The theory behind organic temperature proxies is that certain organisms synthesise molecules with different structures dependent on the environmental conditions (temperature, $\mathrm{pH}$ and so on) to which they are subjected (e.g. Castañeda and Schouten, 2011 and references cited therein). Therefore, if these molecules are preserved in a time-series context, it is possible to reconstruct the past environmental conditions from the relative abundance of different structural types.

Glycerol dialkyl glycerol tetraethers (GDGTs) are lipid molecules derived from microbial membranes that have been shown to vary in structure in relation to temperature and $\mathrm{pH}$. Two main groups have been identified: isoprenoid archaeal GDGTs and branched GDGTs, which are believed to be principally derived from bacteria (Weijers et al., 2006).

Archaeal GDGTs have isoprenoid carbon skeletons (Fig. 1), with the number of cyclopentane moieties in the structure having been shown to have a positive relationship with temperature (Gliozzi et al., 1983; Schouten et al., 2002; Wuchter et al., 2004). Of particular interest has been the kingdom Crenarchaeota, which initially was thought to be formed of hyperthermophilic organisms, but has now been shown to include 'cold' planktonic organisms living in lakes and oceans within a 'normal' temperature range $\left(0-30^{\circ} \mathrm{C}\right)$ (DeLong, 1992; Fuhrman et al., 1992). Genomic analysis of enriched or isolated 'cold' Crenarchaeota have shown that they form a separated phylum called Thaumarchaeota (Brochier-Armanet et al., 2008; Spang et al., 2010), which also include some (hyper-)thermophiles (De La Torre et al., 2008). These Thaumarchaeota synthesise the same broad spectrum of isoprenoid GDGTs as hyperthermophilic Crenarchaeota, but also produce crenarchaeol, a GDGT characterised by possession of a cyclohexane moiety (Schouten et al., 2000, 2002; Sinninghe Damsté et al., 2002). The sensitivity of the molecular composition of thaumarchaeotal membrane lipids to temperature has made them strong candidates for use as organic temperature proxies. This has been exploited in the development of the TEX 86 proxy (Schouten et al., 2002), which measures the relative distribution of different isoprenoid GDGTs derived from aquatic Thaumarchaeota. TEX ${ }_{86}$ has principally been used in marine studies, although studies have also been made in continental aquatic contexts (e.g. Powers et al., 2004, 2010; Blaga et al., 2009). Thaumarchaeota, as well as other Archaea, also occur widely in the terrestrial realm (e.g. Buckley et al., 1998; Ochsenreiter et al., 2003; Leininger et al., 2006; Weijers et al., 2006), and their membrane lipids are detectable in soils, albeit at much lower abundance levels than those derived from bacteria, and at much lower abundances than found in the marine realm (Gattinger et al.,
2003; Weijers et al., 2006). However, TEX $_{86}$ is not generally considered a viable proxy for land or soil based palaeothermometry due to the additional contribution of isoprenoid GDGTs from for example, methanogenic Euryarchaeota (Weijers et al., 2006).

Bacterially derived branched GDGTs have a carbon skeleton containing 4-6 branched methyl groups and up to two cyclopentane moieties (Fig. 1). In a global study of GDGTs in soils, Weijers et al. (2007a) demonstrated that mean annual air temperature (MAT) and soil $\mathrm{pH}$ were major controls on the number of methyl branches in bacterial GDGTs, while the number of cyclopentane rings was primarily related to soil $\mathrm{pH}$ alone. This led to the creation of two indices designed to quantify the distribution of the different branched GDGT structures within a sample: MBT reflecting soil $\mathrm{pH}$ and $\mathrm{MAT}$, and $\mathrm{CBT}$ reflecting soil $\mathrm{pH}$. As both these indices have soil $\mathrm{pH}$ as a common factor, it is therefore possible to use the two indices together to derive a calculated MAT. This approach has now been applied mainly to ocean margin sediments (e.g. Weijers et al., 2007b; Schouten et al., 2008).

The use of the MBT/CBT soil derived proxy in lakes has proved problematic, with calculated temperatures consistently coming out colder than measured temperatures (Tierney et al., 2010; Blaga et al., 2010; Pearson et al., 2011). This is hypothesised to be the result of mixed environmental inputs, with branched GDGTs being derived from both transported terrestrial material and in situ production (Tierney and Russell, 2009; Tierney et al., 2010; Pearson et al., 2011). Therefore, recently other statistical techniques have been applied, focusing on regression models and weighted GDGT proxies, which has yielded improved correlations between branched GDGT distribution and lake temperatures (Tierney et al., 2010; Pearson et al., 2011).

The analysis of GDGTs preserved in stalagmites has in principle great potential to provide an organic terrestrial palaeothermometer independent of isotopic records. The strong time-series control provided by $\mathrm{U}$ series disequilibrium dating provides a robust temporal framework within which the temperature records can be set, while the presence of other chemical proxies for climatic and environmental changes (such as fluctuations in rainfall, or changes in the overlying vegetation) would allow investigation of how changes in temperature relate to other changes in the wider environment. However, investigation of the presence and utility of GDGTs in stalagmites has been limited, with Yang et al. (2011) the only in depth investigation we are aware of. Yang et al. (2011) analysed the GDGT content from palaeo and modern speleothem samples in Heshang Cave, China, along with samples of drip-water, bedrock from within the cave, and overlying soils. They found that the stalagmite GDGTs were dominated by archaeal compounds (particularly crenarchaeol), and that both archaeal and bacterial GDGTs differed markedly in stalagmites compared to those in the overlying soils. They therefore hypothesised that GDGTs in stalagmites are primarily cave or aquifer derived. In terms of proxy utility, Yang et al. (2011) concluded that $\mathrm{TEX}_{86}$ might relate to temperature as it showed some correlation $\left(r^{2}=0.51\right.$ for $\mathrm{TEX}_{86}$, and 0.43 for $\mathrm{TEX}_{86}^{\prime}$ ) with depletion in $\delta^{18} \mathrm{O}$ in the calcite, which 

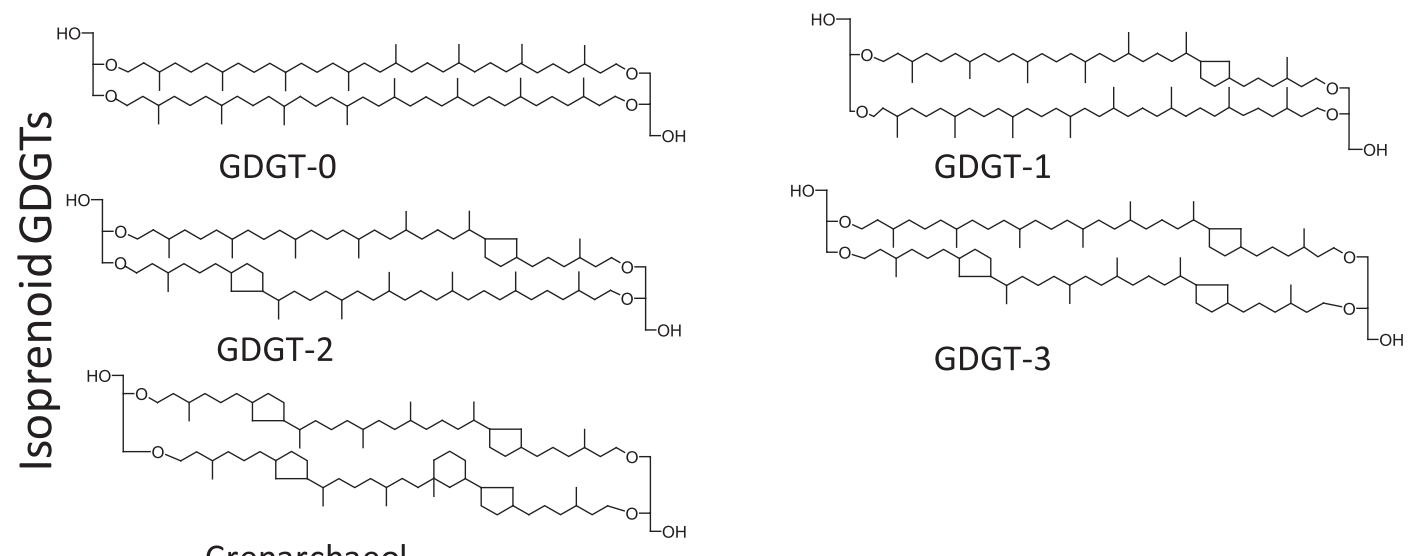

Crenarchaeol
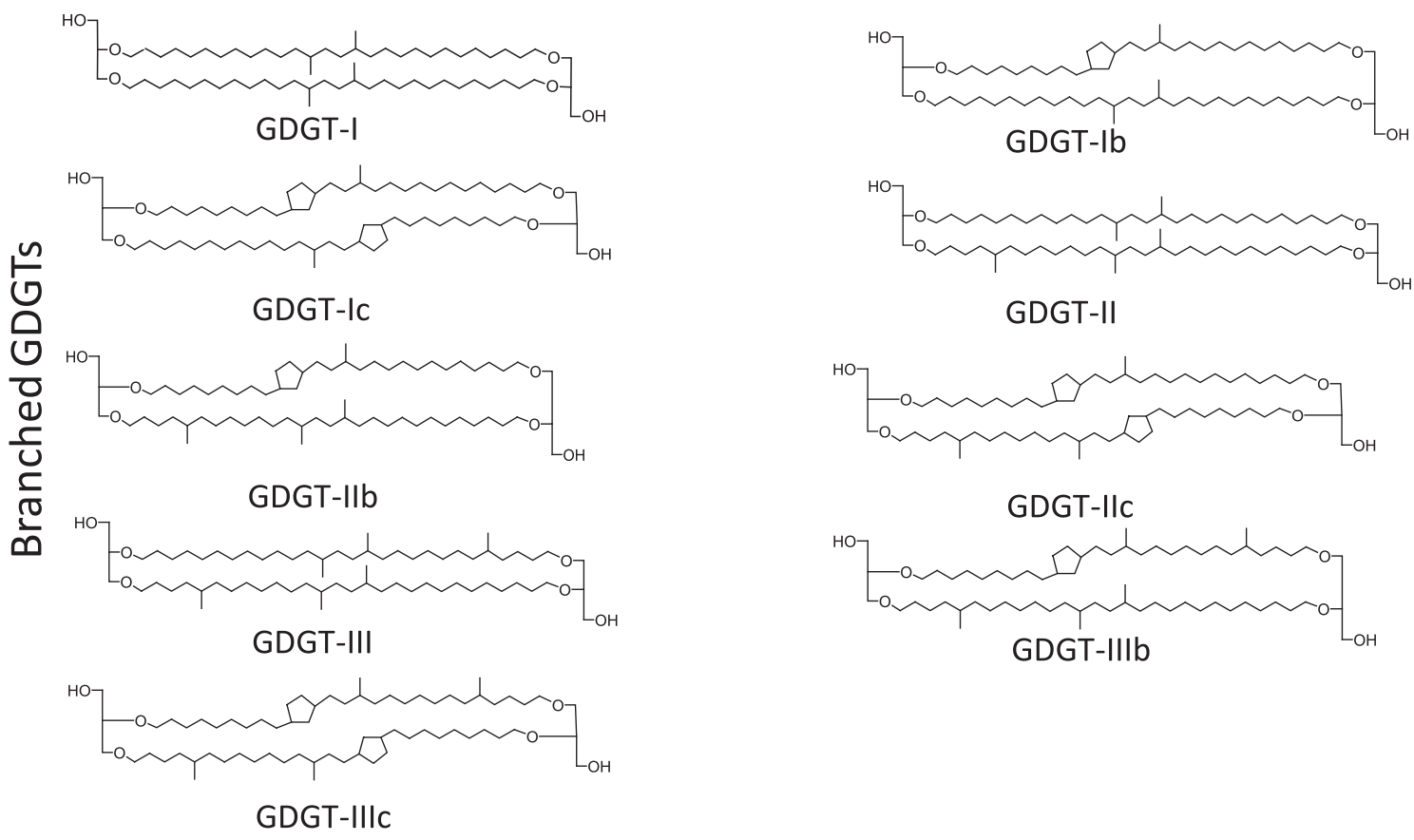

Fig. 1. Isoprenoid and branched GDGT structures.

is related to monsoon intensity (via surface precipitation), which in turn relates to temperature. However, there are a number of reasons why changes in rainfall might influence GDGT composition, including variation of input from different sources with changes in transport flow, and variation in microbial activity with changes in nutrient input and moisture. It is worth noting that, although not commented on in the study, the MBT/CBT index showed a negative correlation with $\delta^{18} \mathrm{O}$ of the same magnitude $\left(r^{2}=0.47\right)$. The study noted that the MBT/CBT index in the modern stalagmites was a poor match for modern temperature, showing a much lower value than expected for the region. However, as this is a record from only one site, and the calibration applied was derived from soils, to judge more comprehensively whether GDGT proxies in stalagmites have potential as reliable temperature proxies, it is necessary to undertake a broader multi-site study, and create speleothem specific calibration equations. Here we therefore analysed the GDGT content of a suite of modern and known age samples to create a new calibration to establish the validity of GDGTs in speleothems as a palaeotemperature proxy.

\section{MATERIAL AND METHODS}

\subsection{Stalagmite sampling and comparative data}

Thirty-three samples from recent stalagmites, straw stalactites, and flowstones from sixteen sites around the word were analysed (Table 1; Fig. 2). These cover a MAT range of $7-26^{\circ} \mathrm{C}$, and were chosen to encompass a range of different climatic zones. Comparative modern surface air temperatures were obtained for 15 sites (data for Nettlebed cave, New Zealand was not available) from measurements published or determined by the original speleothem workers at the sites, and otherwise from the records of the nearest weather station (Table 1). Due to the nature of the temper- 
Table 1

List of samples used in the study.

\begin{tabular}{|c|c|c|c|c|c|c|}
\hline Sample No. & Sample type & Location & Age & $\begin{array}{l}\text { Cave } \\
\text { MAT }\left({ }^{\circ} \mathrm{C}\right)\end{array}$ & $\begin{array}{l}\text { Surface } \\
\text { MAT }\left({ }^{\circ} \mathrm{C}\right)\end{array}$ & Reference for MAT $\left({ }^{\circ} \mathrm{C}\right)$ \\
\hline $\begin{array}{l}\text { Tar-1 } \\
\text { Tar Aa } \\
\text { Tar Ab } \\
\text { Tar Ac } \\
\text { Tar Ae } \\
\text { Tar Af } \\
\text { Tar Ag } \\
\text { Tar Ah } \\
\text { Tar Ai } \\
\text { Tar Aj }\end{array}$ & Broken straw & Uamh am Tartair, Scotland & Recent/Holocene & 7.2 & 7.1 & Fuller et al. (2008) \\
\hline $\begin{array}{l}\text { MD-3 } \\
\text { Net-1 }\end{array}$ & $\begin{array}{l}\text { Stalagmite } \\
\text { Straw }\end{array}$ & Nettlebed cave, NZ & Forming at collection & $\begin{array}{l}7 \\
8.2\end{array}$ & $\begin{array}{l}- \\
-\end{array}$ & Hellstrom pers comm \\
\hline Pos-1 & Stalagmite & Postojna cave, Slovenia & Forming at collection (base max 15 years) & 8.4 & 7.8 & $\begin{array}{l}\text { Dominguez-Villar pers } \\
\text { comm }\end{array}$ \\
\hline PC-1 & Stalagmite & Pooles Cavern, England & Past 10 years & 7.9 & 9 & Hartland pers comm \\
\hline $\begin{array}{l}\text { LBM-S2 } \\
\text { LBM-S3 }\end{array}$ & $\begin{array}{l}\text { Stalagmite } \\
\text { Stalagmite }\end{array}$ & Lower Balls Mine, England & Forming at collection ( $\max 100$ years) & 9.8 & 10 & $\begin{array}{l}\text { Dominguez-Villar pers } \\
\text { comm }\end{array}$ \\
\hline Buchan & Stalagmite & Buchan Caves, Victoria, Australia & Forming at collection & - & 12 & http://www.bom.gov.au \\
\hline $\begin{array}{l}\text { BR-10-A } \\
\text { BR-36 } \\
\text { BR-36-A } \\
\text { BR-5-A }\end{array}$ & $\begin{array}{l}\text { Straw/moonmilk } \\
\text { Stalagmite } \\
\text { Straw/moonmilk } \\
\text { Straw/moonmilk }\end{array}$ & Bats Ridge Cave System, Victoria, Australia & Forming at collection & - & 13 & http://www.bom.gov.au \\
\hline WM-4 & Stalagmite & Wombeyan Caves, New South Wales, Australia & Past 40 years & 14.5 & 13.7 & McDonald pers comm \\
\hline EC-2 & Stalagmite & Eagle Cave, Spain & Forming at collection (base max 150 years) & 15.4 & 14 & $\begin{array}{l}\text { Dominguez-Villar pers } \\
\text { comm }\end{array}$ \\
\hline Turk-1 & Stalagmite & Turkey & Forming at collection & 12.7 & 8 & Jex pers comm \\
\hline PDS-5 & Stalagmite & Tuscany, Italy & Forming at collection & - & 16 & Blyth (2007) \\
\hline Wel-C-1 & Straw & Cathedral Cave, Wellington, NSW, Australia & Recent deposits, including on manmade artefacts & - & 16 & http://www.bom.gov.au \\
\hline Wel-C-2 & Flowstone & & & & & \\
\hline $\begin{array}{l}\text { Wel-C-3 } \\
\text { Wel-G-1 }\end{array}$ & $\begin{array}{l}\text { Flowstone on bottle } \\
\text { Straw }\end{array}$ & Gaydon Cave, Wellington NSW, Australia & & & & \\
\hline Lab-S2 & Stalagmite & Labyrinth Cave, Western Australia & Forming at collection & - & 16.4 & Treble pers comm \\
\hline Ach-1 & Stalagmite & Achere Cave, Ethiopia & Holocene & - & 21 & Asrat et al. (2008) \\
\hline Merc-1 & Stalagmite & Rukessia Cave, Ethiopia & Past 100 years & 18.9 & 21 & \\
\hline SC-4 & Stalagmite & Christmas Island & Past 600 years & - & 25.4 & http://www.bom.gov.au \\
\hline
\end{tabular}




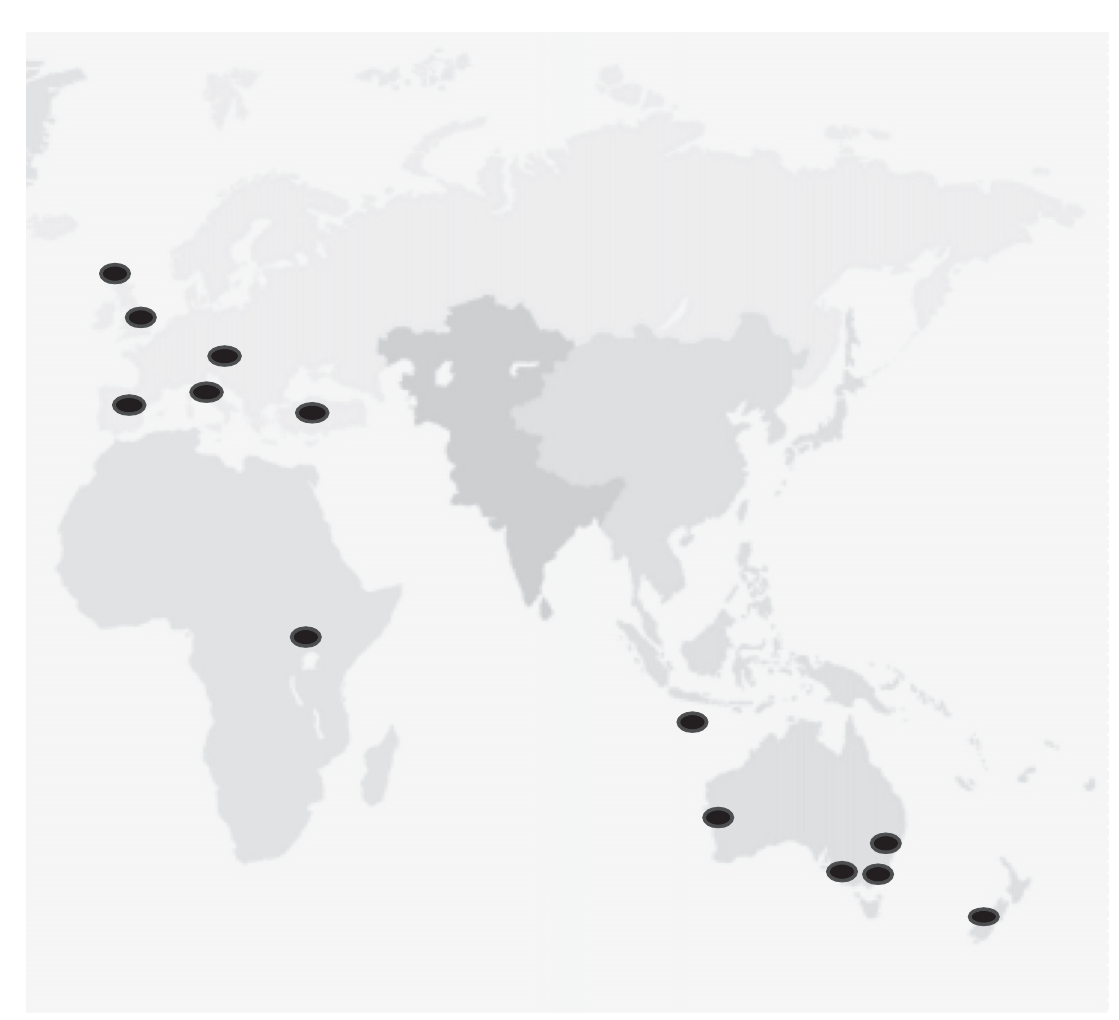

Fig. 2. World map showing distribution of sample sites.

ature data, full information on collection method and errors is not available. This imposes a limitation on our data set (discussed in section 3.6), but does not invalidate it. Where possible ( 8 sites), internal cave temperature data were also obtained from the original speleothem studies. Both cave and surface temperatures are necessary to test the calibrations because cave temperature will be important if GDGTs derive from in situ cave organisms, while surface temperature will be important if GDGTs derive from soil organisms.

Multiple samples are included from single caves (Uamh an Tartair; Cathedral Cave, Wellington), and from separate caves in a single area (Cathedral and Gaydon Cave, Wellington, the Bats Ridge Cave system) in order to test the consistency of the signal at individual sites. Sample choice was dictated by availability and the constraints of cave conservation. However, although these samples are from single areas, they should not be considered true replicates in the way multiple samples from a single speleothem would be, as caves are heterogeneous environments, with variations in microenvironment due to position in the cave, and variations in external input between drip pathways. This is illustrated by the two samples from Nettlebed cave in New Zealand, which have different measured cave temperatures for their collection sites (Table 1).

Calcite samples of 5-20 g were sectioned from stalagmites and flowstones using a $2.5 \mathrm{~cm}$ diamond tipped circular saw attached to a hand drill. Where samples were taken from stalagmites which had been actively depositing at collection, the subsample was taken from the outer (youngest) layers, in order to ensure that the most recent growth was sampled. Straw stalactites were processed intact.

\subsection{Extraction method}

Prior to processing, each sample was cleaned by immersion in $3 \mathrm{M}$ pre-cleaned hydrochloric acid $(\mathrm{HCl})$ to remove the outer $2 \mathrm{~mm}$ surface layer, rinsed in cleaned MilliQ water, and sonicated in dichloromethane (DCM) to remove any remaining organic surface contamination. Samples were individually digested in $3 \mathrm{M} \mathrm{HCl}$, and boiled under reflux at $100{ }^{\circ} \mathrm{C}$ for two hours, which serves to liberate all the GDGTs present, including those from intact polar lipids (Schouten et al., 2013). After cooling, each sample was subject to manual liquid-liquid extraction in DCM, following Blyth et al. (2006). The extracts were separated over an activated $\mathrm{Al}_{2} \mathrm{O}_{3}$ column and eluted sequentially with DCM and DCM/methanol (1:1) following Weijers et al. (2007a). The polar (DCM/methanol) fraction was dried under nitrogen, ultrasonically dissolved in hexane/propanol (99:1), and filtered through a $0.45 \mu \mathrm{m}$ PTFE filter $(\varnothing 4 \mathrm{~mm})$ prior to analysis.

\subsection{Analytical method}

Polar fractions were analysed for GDGTs using high performance liquid chromatography/atmospheric pressure positive ion chemical ionization mass spectrometry (HPLC/APCI-MS) following Schouten et al. (2007). HPLC/APCI-MS analyses were using an Agilent 1100 ser- 
ies LC/MSD SL and separation and a Prevail Cyano column $(2.1 \times 150 \mathrm{~mm}, 3 \mathrm{~mm}$; Alltech $)$, maintained at $30^{\circ} \mathrm{C}$. The glycerol dialkyl glycerol tetraethers (GDGTs) were eluted using a changing mixture of hexane and propanol as follows: $99 \%$ hexane: $1 \%$ propanol for $5 \mathrm{~min}$, then a linear gradient to $1.8 \%$ propanol in $45 \mathrm{~min}$. Flow rate was $0.2 \mathrm{ml}$ per minute. Single ion monitoring was set to scan the $[\mathrm{M}+\mathrm{H}]^{+}$ions of the GDGTs with a dwell time of $237 \mathrm{~ms}$ for each ion. Only peak areas above limit of quantitation were considered.

The following equations were used to calculate the proxy values

$$
\begin{aligned}
\text { TEX }_{86}= & (\text { GDGT } 2+\text { GDGT } 3 \\
& + \text { Cren isomer }) /(\text { GDGT } 1+\text { GDGT } 2 \\
& + \text { GDGT } 3+\text { Cren isomer }) \\
\text { BIT }= & \text { GDGT III }+ \text { GDGT II } \\
+ & \text { GDGT I }) /(\text { Crenarchaeol }+ \text { GDGT III } \\
+ & \text { GDGT II }+ \text { GDGT I }) \\
\text { MBT }= & \text { GDGT I }+ \text { GDGT Ib } \\
& + \text { GDGT Ic }) /(\text { GDGT I }+ \text { GDGT Ib } \\
& + \text { GDGT Ic })+(\text { GDGT II }+ \text { GDGT IIb } \\
& + \text { GDGT IIc })+(\text { GDGT III }+ \text { GDGT IIIb } \\
& + \text { GDGT IIIc })) \\
\text { CBT }= & - \text { LOG }((\text { GDGT Ib }+ \text { GDGT IIb }) /(\text { GDGT I } \\
& + \text { GDGT II })
\end{aligned}
$$

It was not possible to calculate experimental errors for these samples, due to the limited calcite made available, and the low compound abundance preventing replicate runs. However, laboratory and instrument analytical error is known to be typically better than $0.5^{\circ} \mathrm{C}$, based on previous studies (Kim et al., 2010; Weijers et al., 2007a).

\section{RESULTS AND DISCUSSION}

\subsection{GDGT distribution}

The results show that GDGTs are commonly present in and extractable from stalagmite samples of 5-20 g calcite at measurable levels. This is a large calcite sample size compared to some stalagmite techniques, but compares favourably with other organic studies in this context (e.g. Xie et al., 2003; Blyth et al., 2011). Not all samples contained all GDGTs in concentrations above the limit of detection or quantitation, with the crenarchaeol regio-isomer and GDGTs Ic, IIc, IIIc, and IIIb being the least common. Fig. 3 shows a ternary plot of the proportional relationships between GDGT 0, crenarchaeol, and the sum of branched GDGTs I, II, and III. This demonstrates a dominance of crenarchaeol in the majority of samples, although also shows that in a handful of samples, branched GDGTs do predominate. Interestingly, for the multiple samples from Wellington, Lower Balls Mine and to a lesser extent, Tartair, the proportion of GDGT-0 is consistent within each site, but there is variation of $10-20 \%$ between the samples in the proportions of crenarchaeol and branched GDGTs. At Bats Ridge there is a similar distribution of GDGTs in three of the four samples, with the remaining sample showing a lower proportion of crenaracheol and higher proportion of GDGT-0. This within site variability suggests variation in either cave micro-environment or drip source input.

\subsection{BIT index}

The dominance of isoprenoid GDGTs vs branched GDGTs can be expressed in the so-called BIT (Branched and Isoprenoid Tetraether) index, a proxy used in marine environments for the relative input of soil organic matter (Hopmans et al., 2004). The BIT index compares the relative amounts of crenarchaeol, mostly aquatic derived, and soil derived non-isoprenoidal branched GDGTs (Hopmans et al., 2004; Weijers et al., 2006). In open marine environments BIT values tend to be $<0.1$ (Kim et al., 2010) while in soils most BIT values are $>0.9$ (e.g. Weijers et al., 2006). As stalagmites contain distinct signals from soil organic matter (Xie et al., 2003; Blyth et al., 2007, 2010, 2011), it might be expected that they would show a high BIT value due to significant soil derived input. However, the results clearly show that this is not the case, with 28 of the 33 samples (from 12 out of 16 sites) showing a BIT index below 0.5 (Fig. 4). This is in line with the results of Yang et al. (2011), who found BIT values ranging from $0.21-0.58$ in the stalagmite samples from Heshang cave. Our results show that even lower values are common, with twelve of the samples (from 6 sites) having a BIT of 0.1 or below. The BIT values are not consistent between samples from the same site, except at Bats Ridge where all the samples have a BIT of below 0.1. This reflects the within site variation of crenarchaeol and the branched GDGTs seen in the ternary plot (Fig. 3).

The BIT results indicate that a strong in situ cave/aquatic signal dominated by crenarchaeol is present, and that this is a consistent pattern across a wide geographical range of samples. Secondly, the results suggest that cave microbes are not simply immigrant soil organisms, but distinct cave communities. This hypothesis of the presence of crenarchaeol producing organisms in cave microbial communities is supported by microbiological work showing that thaumarchaeotal 16S rDNA sequences have been found in cave deposits (Gonzalez et al., 2006).

\subsection{TEX $_{86}$}

Given the high crenarchaeol abundance observed, suggesting an active thaumarchaeotal community in the cave deposits, it would be reasonable to hypothesise that TEX $_{86}$ might be a suitable proxy to apply. We performed two sets of correlations, plotting $\mathrm{TEX}_{86}$ against MAT derived from local or regional surface air temperature measurements $(n=30$, from 14 sites - one sample/site LABS2 was not included due to too low an abundance of certain GDGTs), and against measured cave air temperature ( $n=19$, from 8 sites). In both cases, $\mathrm{TEX}_{86}$ shows a significant correlation $\left(r^{2}=0.78, p<0.001\right.$ for surface MAT, 


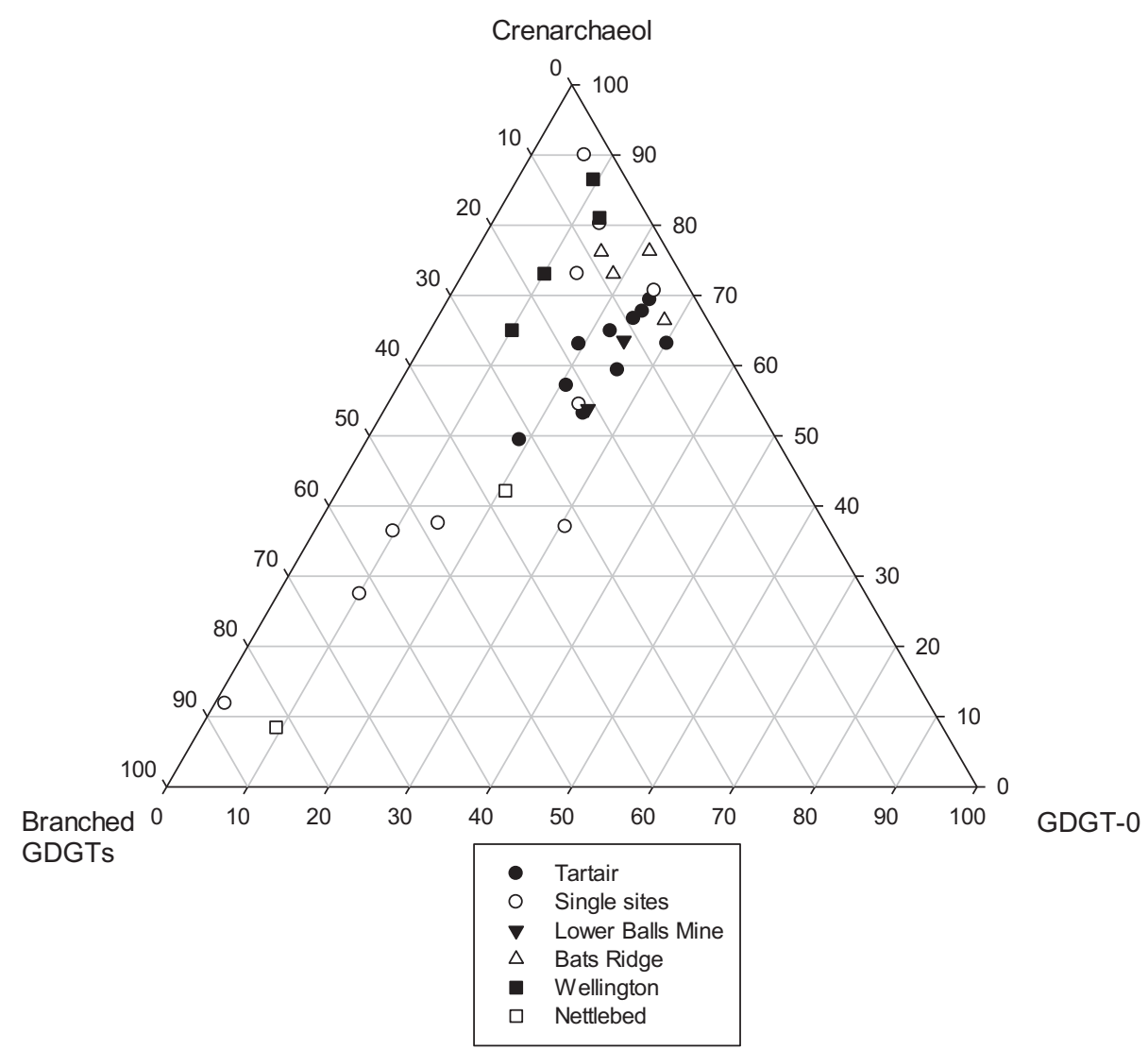

Fig. 3. Ternary plot showing the relative distributions of GDGT-0, crenarchaeol, and the sum of branched GDGTs I, II, and III.

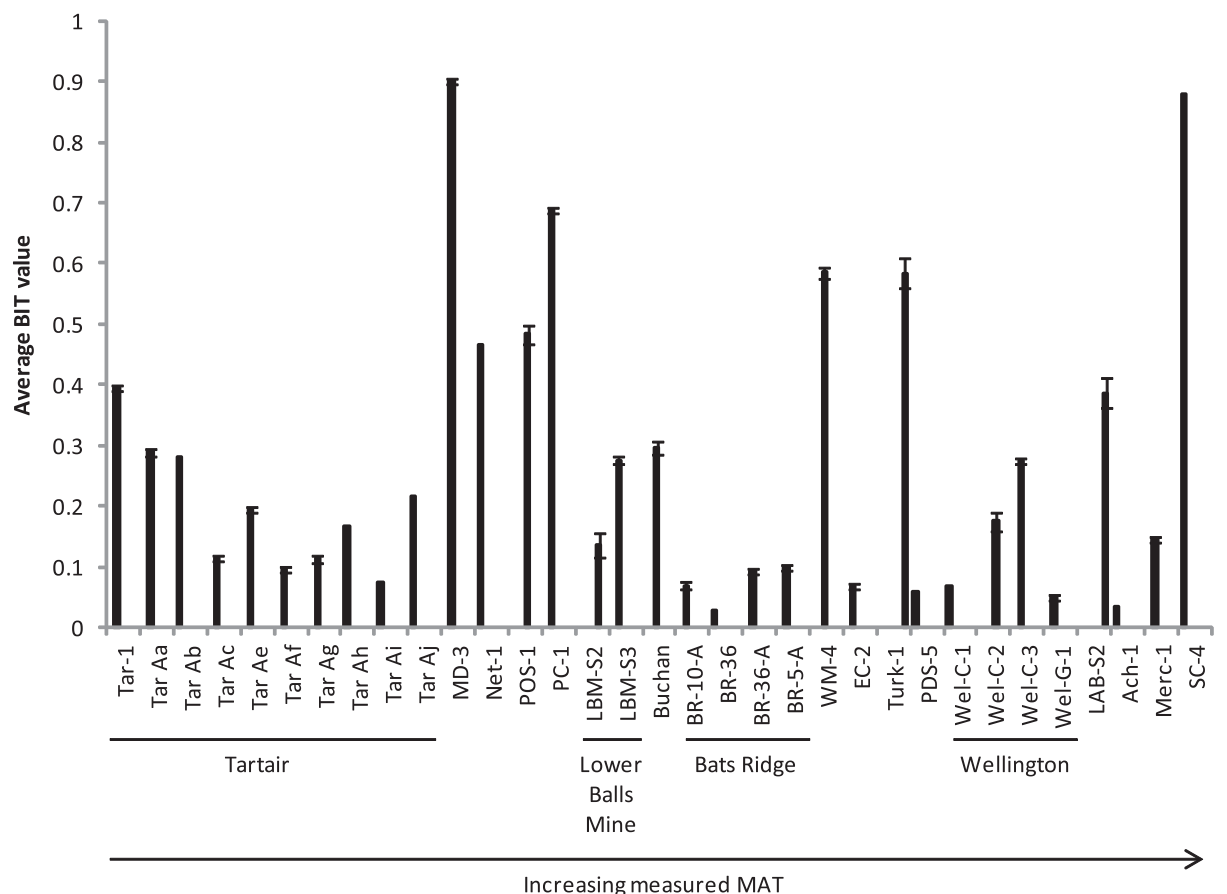

Fig. 4. Average BIT value for samples analysed in this study. Average BIT values were measured in duplicate and error bars represent the difference between the two measurements. 
$r^{2}=0.68, p<0.001$ for cave MAT) (Fig. 5; Table 2). This indicates that a temperature dependent signal is being recorded.

One method to improve $\mathrm{TEX}_{86}$ correlations is to exclude samples with high BIT values, therefore excluding samples with significant external soil input which may blur the autochtonous signal. This approach has been used in marine sediments whereby BIT values $>0.3$ are thought to signal a potential bias in TEX $_{86}$ values. (Weijers et al., 2006). This criterion has also been applied in lakes, and shown to improve calibrations, but in that context has been complicated by the small sample set remaining (Blaga et al., 2009; Powers et al., 2010; Bechtel et al., 2010; Pearson et al., 2011). Due to the persistently low BIT seen in this study, it is possible to exclude samples with a BIT of $\geqslant 0.5$, and still maintain a reasonable sample set of $n=27$ (from 11 sites) for surface MAT calibration and $n=16$ (from 6 sites) for the cave MAT calibration. However, trimming the data set in this way does not make a substantial difference to the calibrations (Fig. 6; Table 2), with the calibration with surface temperature having an $r^{2}$ of 0.77 , and with cave temperature an $r^{2}$ of 0.70 . The latter is a slight improvement, but as can be seen from Fig. 6a, the correlation is mainly driven by only two samples with high measured MAT. There is no reason to treat these points as abnormal outliers and remove them from the data set, but until additional samples with cave temperature measurements from the mid and high temperature ranges can be obtained, this calibration is currently not very robust. In both the surface and cave datasets, exclusion on BIT $>0.5$ improves the standard error of the estimate by $0.1{ }^{\circ} \mathrm{C}$ only. As the changes to the calibration equation are therefore not substantial, and do reduce the sample set, at present we do not consider it advisable to exclude data points by BIT in this context, although it may become appropriate during future work.For $\mathrm{TEX}_{86}$, measured in the full sample set, we therefore have calibration equations of:

$$
\begin{aligned}
& \text { Surface MAT }=-7.4+\left(33.3 * \mathrm{TEX}_{86}\right) \\
& \left(r^{2}=0.78 ; p<0.001 ; \text { standard error of the estimate }=2.3^{\circ} \mathrm{C}\right)
\end{aligned}
$$

Cave MAT $=-7.3+\left(32.2 * \mathrm{TEX}_{86}\right)$

$$
r^{2}=0.68 ; p<0.001 \text {; standard error of the estimate }=2{ }^{\circ} \mathrm{C}
$$

The standard errors of the regression in these calibrations compare favourably to previous studies in other contexts. In marine sediments Kim et al. (2010) reported standard errors of $2.5^{\circ} \mathrm{C}$ for the $\mathrm{TEX}^{\mathrm{H}}{ }_{86}$ excluding polar oceans. In lakes, Powers et al. (2010) found an estimated temperature error of $3.6^{\circ} \mathrm{C}$ in a data set with high BIT sam-

a
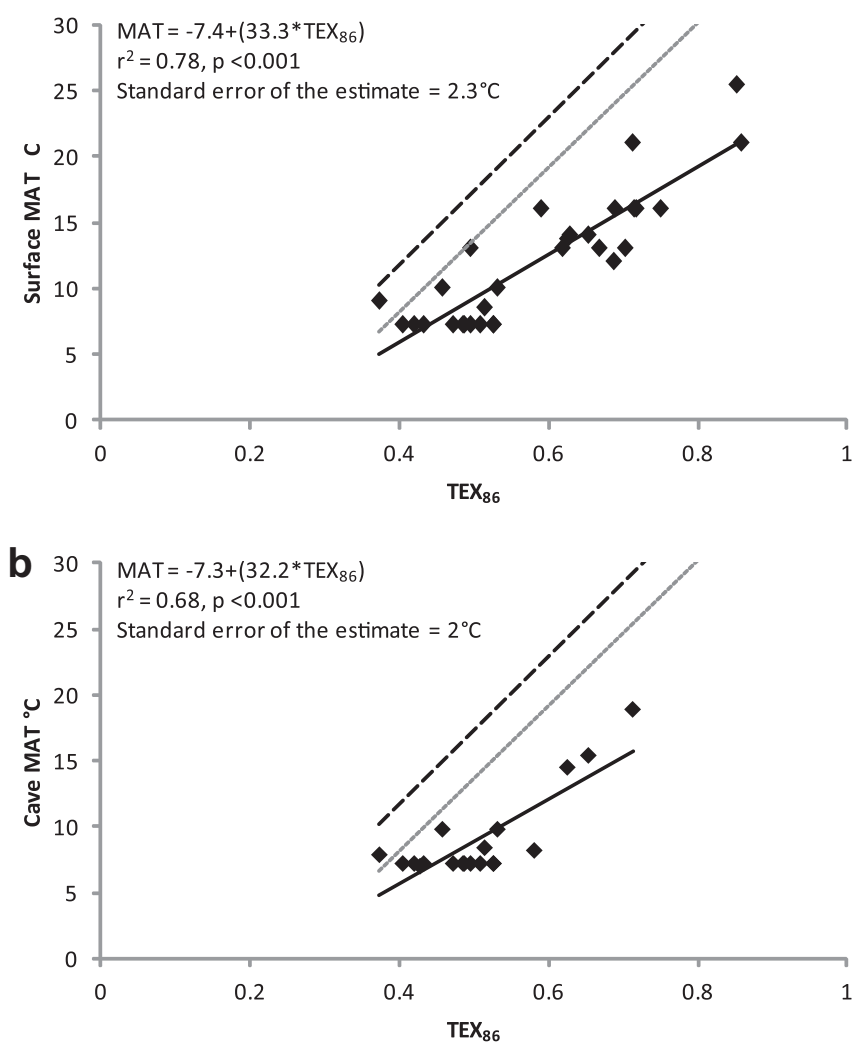

Fig. 5. Scatter graphs showing the correlations between $\mathrm{TEX}_{86}$ and (a) surface MAT, and (b) cave MAT. The black dashed line is the marine calibration line for Kim et al. (2008), the grey dotted line is the lakes calibration line for Powers et al. (2010). 
Table 2

Main statistics for the $\mathrm{TEX}_{86}$ and MBT/CBT correlations discussed in the text and figures.

\begin{tabular}{|c|c|c|c|c|}
\hline Correlation & Equation & $r^{2}$ & $p$ & $\begin{array}{l}\text { Standard error of } \\
\text { the estimate }\left({ }^{\circ} \mathrm{C}\right)\end{array}$ \\
\hline TEX $_{86}$ vs surface MAT & $\mathrm{MAT}=-7.4+\left(33.3 * \mathrm{TEX}_{86}\right)$ & 0.78 & $<0.001$ & 2.3 \\
\hline TEX $_{86}$ vs cave MAT & MAT $=-7.3+\left(32.2 *\right.$ TEX $\left._{86}\right)$ & 0.68 & $<0.001$ & 2.0 \\
\hline TEX $_{86}$ vs surface MAT (BIT $<0.5$ excluded) & MAT $=-7.1+\left(32.1 *\right.$ TEX $\left._{86}\right)$ & 0.77 & $<0.001$ & 2.2 \\
\hline TEX $_{86}$ vs cave MAT $($ BIT $<0.5$ excluded $)$ & $\mathrm{MAT}=-9.2+\left(35.2 * \mathrm{TEX}_{86}\right)$ & 0.70 & $<0.001$ & 1.9 \\
\hline TEX $_{86}$ vs surface MAT (cave \& surface dataset, Fig. 11) & MAT $=-8.1+\left(34.2 * \mathrm{TEX}_{86}\right)$ & 0.65 & $<0.001$ & 2.5 \\
\hline TEX $_{86}$ vs cave MAT (restricted dataset, Fig. 11) & $\mathrm{MAT}=-8.3+\left(34.4 * \mathrm{TEX}_{86}\right)$ & 0.73 & $<0.001$ & 1.9 \\
\hline MBT vs surface MAT & $\mathrm{MAT}=22.8 * \mathrm{MBT}+5.6$ & 0.62 & $<0.001$ & 3.2 \\
\hline MBT vs cave MAT & $\mathrm{MAT}=21.9 * \mathrm{MBT}+4.3$ & 0.38 & 0.009 & 2.9 \\
\hline CBT vs surface MAT & $\mathrm{MAT}=0.3 * \mathrm{CBT}+12.3$ & 0.00 & 0.898 & 5.1 \\
\hline CBT vs cave MAT & $\mathrm{MAT}=-5.8^{*} \mathrm{CBT}+10.8$ & 0.20 & 0.069 & 3.3 \\
\hline MBT vs CBT vs surface MAT & $\mathrm{MAT}=5.4+(27.1 * \mathrm{MBT})-(4.8 * \mathrm{CBT})$ & 0.73 & $<0.001$ & 2.7 \\
\hline MBT vs CBT vs cave MAT & $\mathrm{MAT}=6.1+(21.3 * \mathrm{MBT})-(5.4 * \mathrm{CBT})$ & 0.56 & 0.003 & 2.5 \\
\hline MBT vs CBT vs surface MAT (cave $\&$ surface data-set) & $\mathrm{MAT}=6.0+(20.9 * \mathrm{MBT})-(4.5 * \mathrm{CBT})$ & 0.44 & 0.031 & 3.2 \\
\hline MBT vs CBT vs cave MAT (cave $\&$ surface data-set) & $\mathrm{MAT}=6.6+(20.2 * \mathrm{MBT})-(5.8 * \mathrm{CBT})$ & 0.56 & 0.007 & 2.7 \\
\hline MBT/CBT calculated MAT vs surface MAT & Calc MAT $=3.4+(0.7 *$ surface MAT $)$ & 0.73 & $<0.001$ & 2.3 \\
\hline MBT/CBT calculated MAT vs cave MAT & Calc MAT $=4.0+(0.6 *$ cave MAT $)$ & 0.56 & $<0.001$ & 1.8 \\
\hline
\end{tabular}
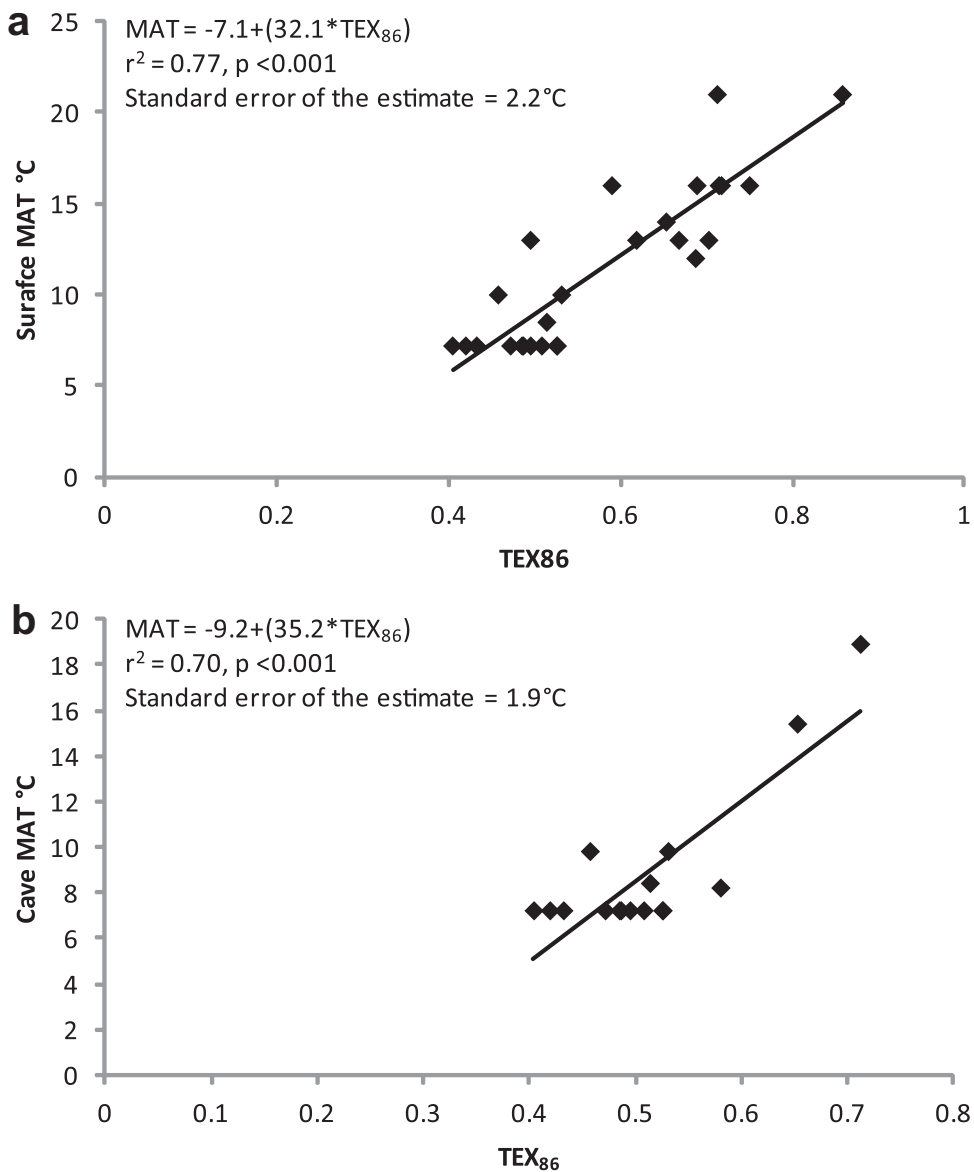

Fig. 6. Scatter graphs showing $\mathrm{TEX}_{86}$ correlations with samples with BIT $\geqslant 0.5$ excluded, (a) surface MAT, (b) cave MAT.

ples removed. As can be seen from Fig. 5, the calibration line is quite different to those from Kim et al. (2008) or Powers et al. (2010), with a much lower slope, and a slightly higher intercept. This supports the argument for the development of calibrations specific to the cave context.
A reported potential problem of application of the TEX $_{86}$ proxy is input from methanogenic and methanotrophic archaea. As this has been found to render the proxy problematic in terrestrial contexts (Weijers et al., 2006), it is necessary to identify if this has been the case here. Blaga 
et al. (2009) proposed that a ratio of GDGT-0/crenarchaeol $>2$ signifies an important contribution of methanogenic archaea to the pool of GDGTs. Application of this threshold to our data shows no sample with a ratio $>2$ (31 samples have a ratio of $\leqslant 0.5$, while sample MD3 has a ratio of 1.1 and POS-1 a ratio of 0.8). Methanogenic input does not therefore seem to be an issue in this context. Other potential influences on the proxy such as $\mathrm{pH}$ could not be determined in this study due to the unavailability of background data, but should be considered in future work.

\subsection{MBT/CBT proxy}

Two samples, Turk-1 and LBM-S3 were removed from the data set for MBT/CBT calculations due to branched GDGT peaks below the limit of quantitation. This provided a total sample set of 28 samples from 14 sites for correlation with surface MAT, and 17 samples from 8 sites for correlation with measured cave MAT. Table 2 displays the main statistics for the various correlations.

Fig. 7 shows the results of plotting MBT and CBT separately against the measured surface and cave MAT. CBT has previously been proposed as being driven by the $\mathrm{pH}$ conditions, and MBT by a combination of $\mathrm{pH}$ and temperature (Weijers et al., 2007a). In this study we were unable to obtain sufficient $\mathrm{pH}$ data for all sites, which means that, until modern process work is completed for a range of caves, we cannot assess whether CBT acts as a proxy for $\mathrm{pH}$ as in soils. At one site (Buchan), where we have been able to make $\mathrm{pH}$ measurements, the soil $\mathrm{pH}$ range is $6.8-7.5$, while the cave drip-water $\mathrm{pH}$ is $6.9-8$. The CBT derived $\mathrm{pH}$ for this site is 8 , suggesting that $\mathrm{CBT}$ may indeed reflect $\mathrm{pH}$. It can also be seen that there is one outlier in the data set compared with surface temperature (SC-4 from Christmas Island) which has an abnormally high CBT compared to the rest of the samples. This CBT results in a calculated $\mathrm{pH}$ for this sample of 4.3, which certainly initially seems unrealistic. However, this sample has an unusual calcite fabric and trace element profile, and it is hypothesised that microbes may have been actively modifying the microenvironment on areas of the speleothem surface, reducing the $\mathrm{pH}$ and causing microdissolution of the calcite (Frisia, pers. comm.).

Fig. 7 shows that there is no significant relationship between CBT and either measured temperature, as with soils (Weijers et al., 2007a), but a reasonable correlation $\left(r^{2}=0.62\right)$ between MBT and surface MAT. Cave MAT has a weak correlation with MBT of $r^{2}=0.38$. Following Weijers et al. (2007a) and Sun et al. (2011) a multiple regression was carried out between measured MAT, CBT and MBT. The 3D plot for the surface MAT data set is shown in Fig. 8a, and gives an equation of:

$$
\begin{aligned}
& \text { Surface MAT }=5.38+(27.1 * \mathrm{MBT})-(4.8 * \mathrm{CBT}) \\
& \quad\left(r^{2}=0.73, p<0.001, \text { standard error of the estimate }=2.7^{\circ} \mathrm{C}\right)
\end{aligned}
$$

a
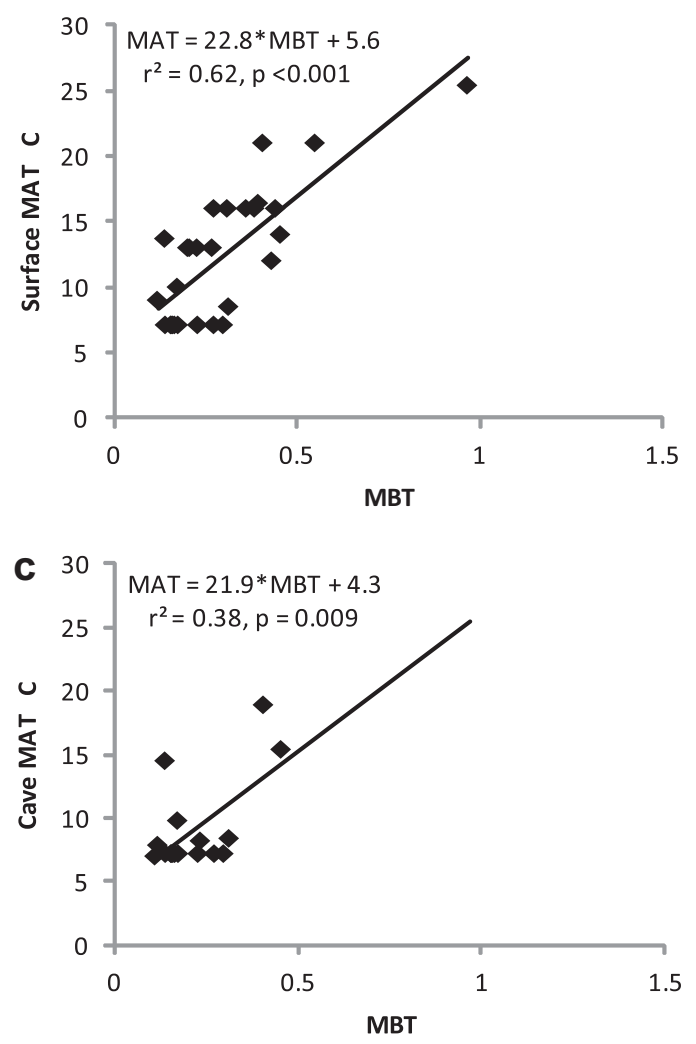

b
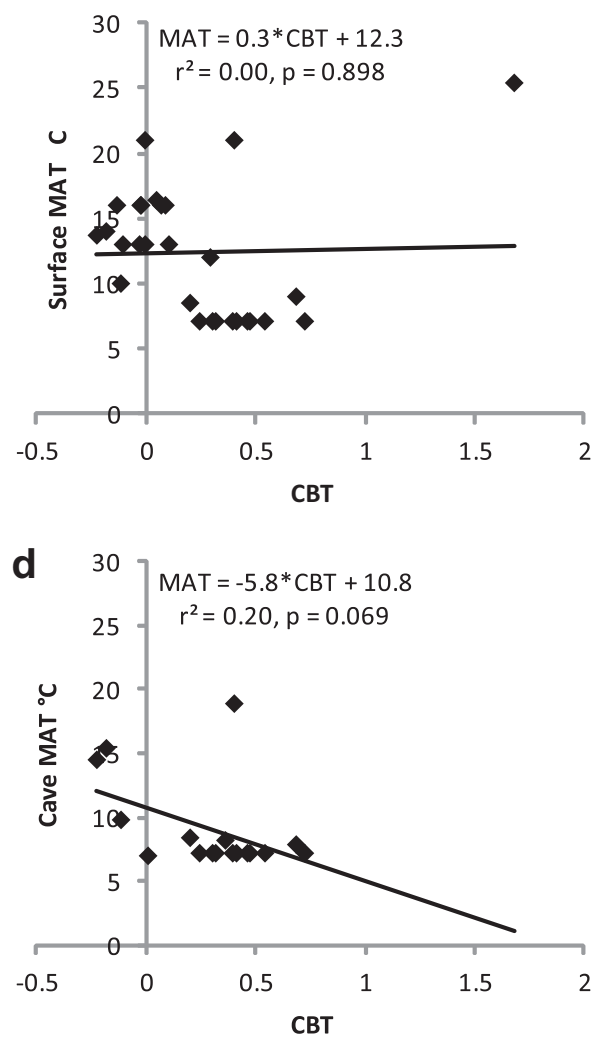

Fig. 7. Linear correlations between surface MAT and (a) MBT, (b) CBT; and between cave MAT and (a) MBT, (b) CBT. 


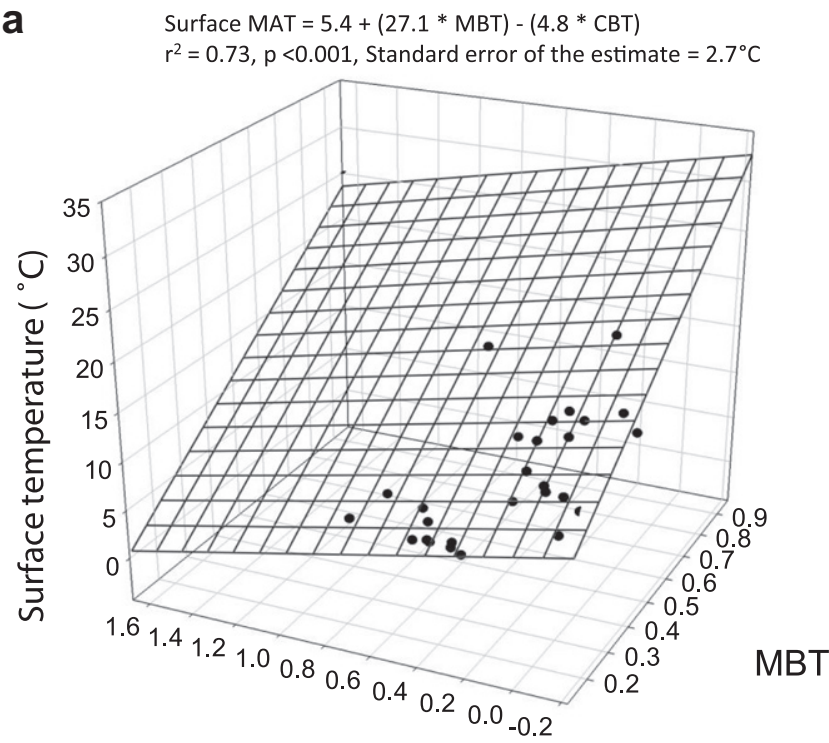

CBT

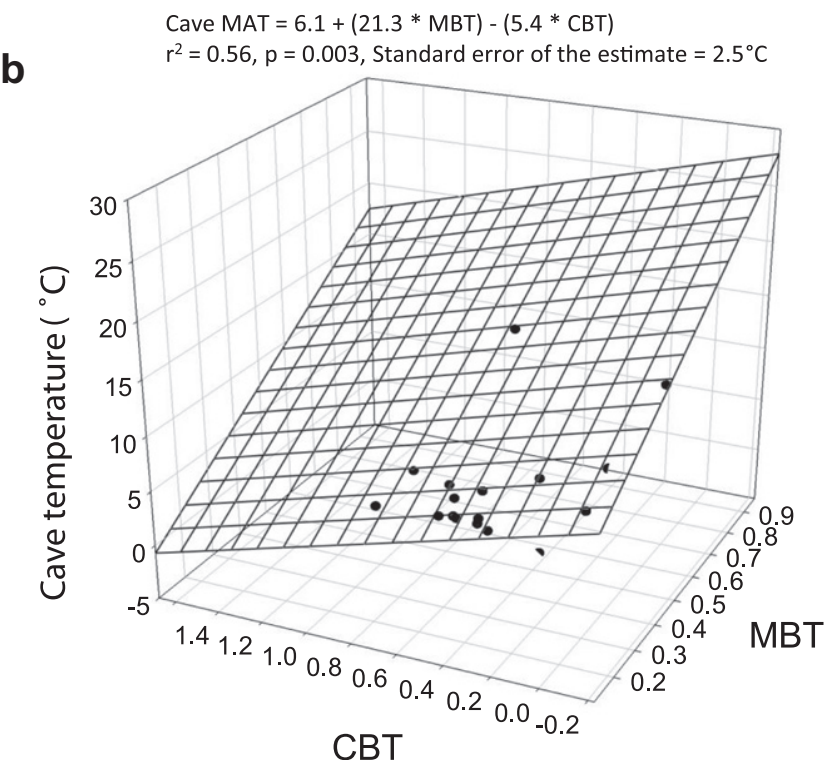

Fig. 8. 3D correlations between (a) MBT, CBT, and surface MAT; (b) MBT, CBT, and cave MAT.

The multilinear regression was then repeated for the reduced sample set with available cave temperature data (Fig $8 b)$. This gave an equation of:

$$
\begin{aligned}
& \text { Cave MAT }=6.06+(21.3 * \mathrm{MBT})-(5.4 * \mathrm{CBT}) \\
& \quad\left(r^{2}=0.56, p=0.003, \text { standard error of the estimate }=2.5^{\circ} \mathrm{C}\right)
\end{aligned}
$$

In both regressions $\mathrm{MBT}$ and $\mathrm{CBT}$ both contributed significantly to the regression model.

The improved correlation of surface MAT with both CBT and MBT compared to MBT alone suggest, like in soils (Weijers et al., 2007a), that a multilinear regression is needed. The degree of correlation of the surface MAT calibration of Eq. (7), and particularly the standard error of the estimate compares favourably with those of MBT/ CBT calibrations in other contexts. In the Weijers et al. (2007a) the original soil calibration had an $r^{2}$ of 0.77 with a standard error of $5^{\circ} \mathrm{C}$ (Weijers et al., 2007b). In a global lakes calibration, Sun et al. (2011) reported $r^{2}=0.62$, with a standard error of $5.2^{\circ} \mathrm{C}$ across the whole data set, and $r^{2}=0.73$ with an error of $4.3^{\circ} \mathrm{C}$ when highly alkaline lakes were excluded. A recent recalibration of the MBT/CBT for soils reported an $r^{2}$ of 0.59 with a standard error of $5^{\circ} \mathrm{C}$ (Peterse et al., 2012). Fig. 9 shows plots of measured vs calculated MAT using our speleothem based calibration, with the relevant regression lines from the equations of Sun et al. (2011) and Weijers et al. (2007a). The speleothem correlations have a lower slope than either of the other calibra- 
tions, and produces intermediate calculated temperatures, which begin to converge with the lakes calibration in colder samples $\left(<10^{\circ} \mathrm{C}\right)$ and the soils calibration in hotter climates $\left(>20^{\circ} \mathrm{C}\right)$.

As lake studies have shown that weighted branched GDGT calibration might be more suitable than the MBT/CBT, we tested the equations of Tierney et al. (2010), and Pearson et al. (2011) on our data set. Both these calibrations give a much poorer correlation in stalagmites than the MBT/CBT calibration, with $r^{2}$ values of 0.32 and 0.45 respectively against surface temperature (data not shown). We therefore propose that in cave contexts, a non-weighted MBT/CBT based calibration is currently more appropriate for branched GDGT data.

\subsection{Local variability within cave deposits}

Caves are potentially heterogeneous environments, with micro-environmental variations dependent on position within the cave (depth, airflow, moisture), and external source input varying with drip pathway and flow rate. To examine the variations in GDGT composition within cave sites, and the effect on the temperature correlations, we took multiple samples at four sites, Tartair (Scotland), Lower Balls Mine (England), Bats Ridge (Victoria, Australia), and Wellington (NSW, Australia). For Tartair, nine separate broken straw stalagmites from the same chamber of a single cave were analysed for MBT/CBT, and ten for TEX $_{86}$. At Lower Balls Mine, two stalagmite samples were collected from beneath different drip points. Both produced sufficiently abundant GDGTs to calculate $\mathrm{TEX}_{86}$ values, but only LBM-S2 contained all the required branched GDGTs above the limit of quantitation. At Bats Ridge, straw stalactites encrusted with moonmilk were taken from three caves on the same property (BR-36, BR-10, and BR5) with a modern stalagmite sample also taken from BR-36. At Wellington, two caves on the same reserve were sampled, with straw stalactites being collected from Gaydon Cave, and separate samples of straw stalactites, natural flowstone, and flowstone overgrowth from a drip-collection bottle collected from Cathedral Cave.

As seen in Figs. 3 and 4, there is variation in the broad GDGT composition within Tartair and Wellington, especially with respect to the relative proportions of crenarchaeol and the branched GDGTs, although not GDGT-0. Fig. 10 and Table 3 show the variation in the different sam-

a
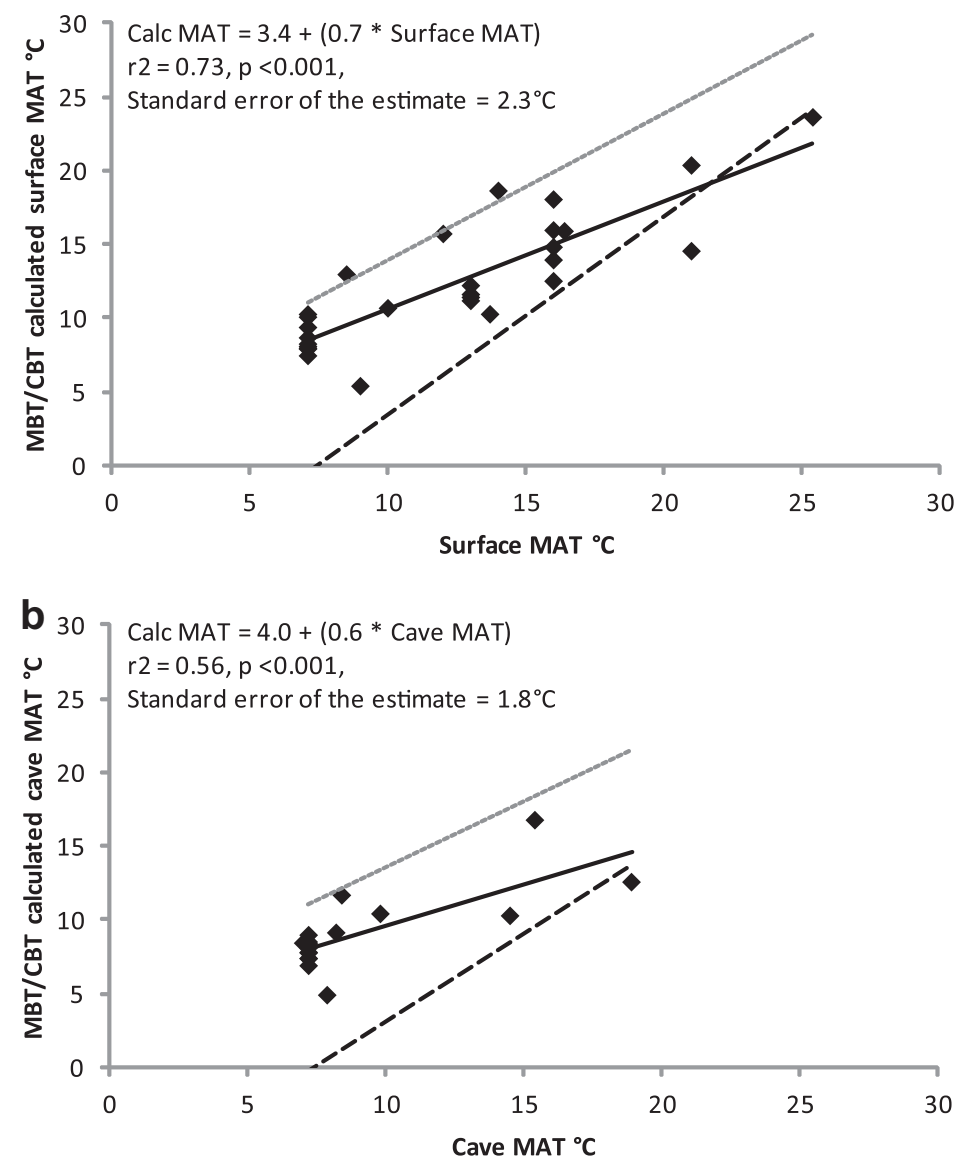

Fig. 9. Scatter plots showing the relationship between (a) surface MAT and MBT/CBT calculated temperature using Eq. (7); (b) cave MAT and MBT/CBT calculated temperature using Eq. (8). Black dashed line shows the regression trend using the soils calibration of Weijers et al. (2007a), grey dotted line shows the regression trend using the lakes calibration of Sun et al. (2011). 

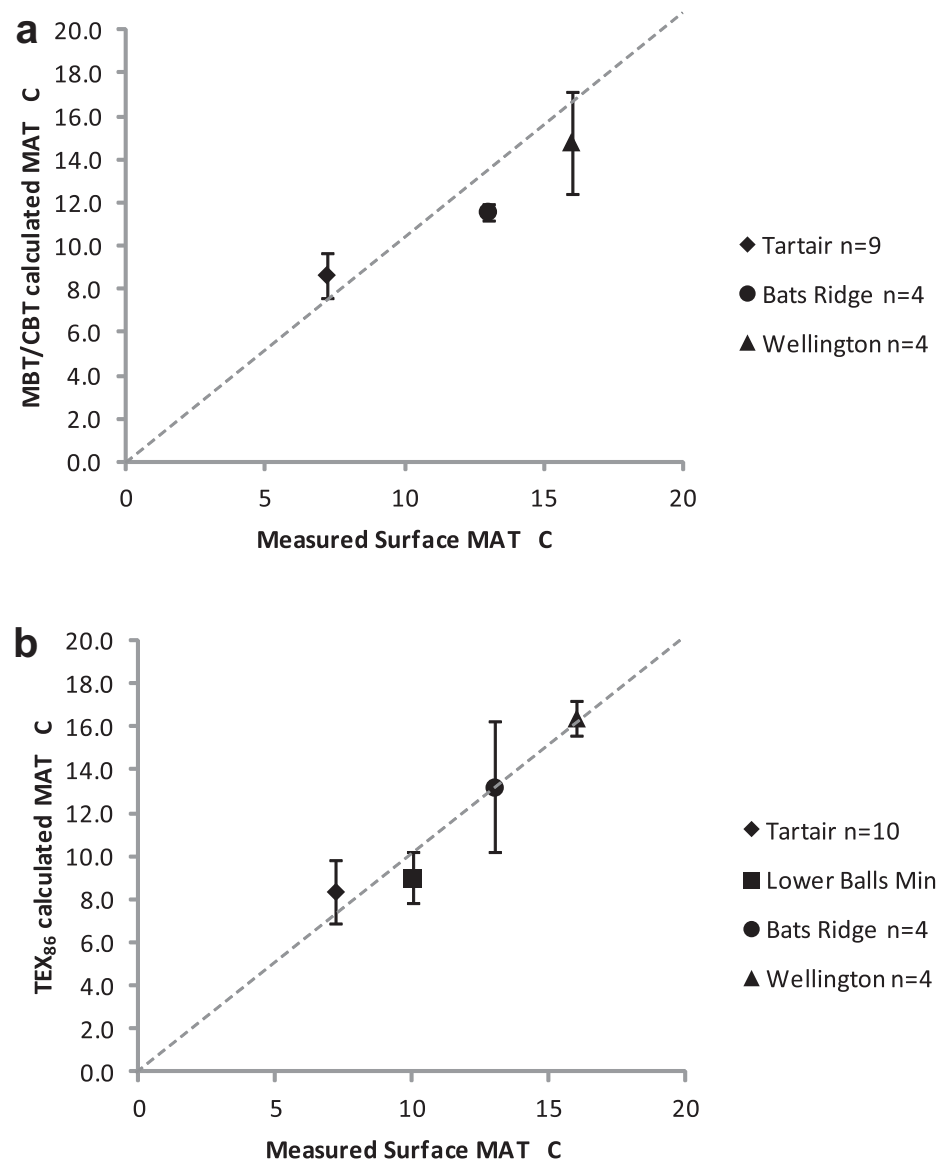

- Tartair $\mathrm{n}=10$

- Lower Balls Mine $\mathrm{n}=2$

- Bats Ridge $\mathrm{n}=4$

$\Delta$ Wellington $\mathrm{n}=4$

Fig. 10. Plots showing the within site variability in the MBT/CBT surface calibration (a) and $\mathrm{TEX}_{86}^{\mathrm{H}}$ (b) against surface MAT. Error bars are \pm 1 SD (except for Lower Balls Mine which shows the range), grey dotted line is the 1:1 line for measured and calculated temperature.

Table 3

Means and standard deviations of the calculated temperatures at the sites where multiple speleothem samples were taken.

\begin{tabular}{lllllll}
\hline Site & $\begin{array}{l}\text { Sample } \\
\text { number }\end{array}$ & Surface MAT $\left({ }^{\circ} \mathrm{C}\right)$ & $\begin{array}{l}\text { Mean MAT } \\
\left({ }^{\circ} \mathrm{C}\right) \mathrm{TEX}_{86}\end{array}$ & $\begin{array}{l}\text { Standard } \\
\text { deviation TEX }\end{array}$ & $\begin{array}{l}\text { Mean MAT }\left({ }^{\circ} \mathrm{C}\right) \\
\text { MBT/CBT }\end{array}$ & $\begin{array}{l}\text { Standard deviation } \\
\text { MBT/CBT }\end{array}$ \\
\hline Tartair $\left(\mathrm{TEX}_{86}\right)$ & 10 & 7.1 & 8.4 & 1.44 & 8.6 & 1.01 \\
Lower Balls Mine $\left(\mathrm{TEX}_{86}\right)$ & 2 & 10 & 9.0 & $1.20($ range/2) & - & - \\
Bats Ridge $\left(\mathrm{TEX}_{86}\right)$ & 4 & 13 & 13.2 & 3.02 & 11.6 & 0.40 \\
Wellington $\left(\mathrm{TEX}_{86}\right)$ & 4 & 16 & 16.4 & 0.83 & 14.8 & 2.34 \\
\hline
\end{tabular}

ple groups when our TEX 86 , and MBT/CBT equations (calibrated to surface MAT) are applied. It can be seen that there is variation in the precision of the two proxies, with $\mathrm{TEX}_{86}$ showing a smaller standard deviation at Wellington Caves, while the MBT/CBT proxy has a lower standard deviation at Bats Ridge. The standard deviation for the Tartair samples is similar in both proxies. For the MBT/ CBT proxy, the standard deviation at each site is within the standard error of the estimate for the calibration $\left(2.7^{\circ} \mathrm{C}\right)$. For $\mathrm{TEX}_{86}$ the standard deviations at Bats Ridge $\left(3{ }^{\circ} \mathrm{C}\right)$ falls just outside the error for the calibration $\left(2.3^{\circ} \mathrm{C}\right)$. In terms of accuracy of the temperature calculation, the $\mathrm{TEX}_{86}$ calibration places the mean for each site slightly nearer the 1.1 line. These results suggest that there is some within cave variability of the proxy values which causes part of the scatter in our proxy calibrations. We hypothesise that this variability is due to a combination of small scale variability in microbial populations and temperature within a given site, and variations in drip input. However, this variability is largely within the error of the calibration, and does not therefore have major implications for palaeo applications. At present it is not simple to identify characteristics in the broader GDGT data set that might indicate which proxy would be most applicable at a specific site. For example, it might be thought that BIT values could indicate whether $\mathrm{TEX}_{86}$ or the MBT/CBT proxy would be more appropriate, with high BIT values potentially biasing $\mathrm{TEX}_{86}$. However, these results suggest that a low BIT does 
not in itself indicate applicability of $\mathrm{TEX}_{86}$ or contra-indicate use of MBT/CBT, with Bats Ridge (where MBT/CBT gives the best repeatability) having a lower range of BIT values than Wellington (0.03-0.1, as opposed to 0.05-0.28).

\subsection{Implications for application of GDGT proxies in stalagmites}

The results indicate that both $\mathrm{TEX}_{86}$, and $\mathrm{MBT} / \mathrm{CBT}$ have potential for use as temperature proxies in speleothems, showing significant correlations with measured temperature. Overall, the $\mathrm{TEX}_{86}$ proxy appears more generally suitable with a higher $r^{2}$ value ( 0.78 against surface MAT) when measured temperature is correlated against proxy temperature, and a lower standard error of estimate $\left(2.3^{\circ} \mathrm{C}\right)$, a finding that can probably be attributed to the predominance of crenarchaeol in the samples. However, the MBT/CBT proxy also has an $r^{2}(0.73)$ and a standard error of estimate $\left(2.7^{\circ} \mathrm{C}\right)$ comparable to the proxy calibrations in other contexts, and our site specific repeats indicate that at some sites, such as the Bats Ridge cave system, the MBT/CBT proxy may be more suitable. At this early stage of proxy development, while we do not have prior indicators to identify the most applicable proxy, we would suggest measuring and reporting both to be the most conservative and robust approach.

An outstanding issue to be resolved is whether in the long-term speleothem GDGT proxies are best calibrated against surface air temperature or against cave temperature. Given that we have demonstrated that the GDGT signal in speleothems is dominated by crenarchaeol, and appears to have an in situ cave/aquatic character, it would be logical to hypothesise that cave temperature will provide the better correlation. The results here show consistently stronger correlations with surface air temperature, however, this may be a function of sample size, with only a limited number of cave temperature measurements being available compared to surface MAT. To test this hypothesis, we correlated TEX $_{86}$ against surface MAT (Fig. 11), but this time using a restricted data containing only samples for which we have both cave and surface MAT measurements ( $n=17$, from 7 sites). Our hypothesis was that if cave temperature is a better comparator, then the $r^{2}$ for the cave MAT correlation should be higher than the $r^{2}$ for the surface MAT correlation on the same sample set. Indeed, the cave correlation of $r^{2}=0.73(p<0.001$; standard error of the estimate $=1.9^{\circ} \mathrm{C}$ ) is higher than that of the surface MAT correlation with $r^{2}=0.65(p<0.001$; standard error
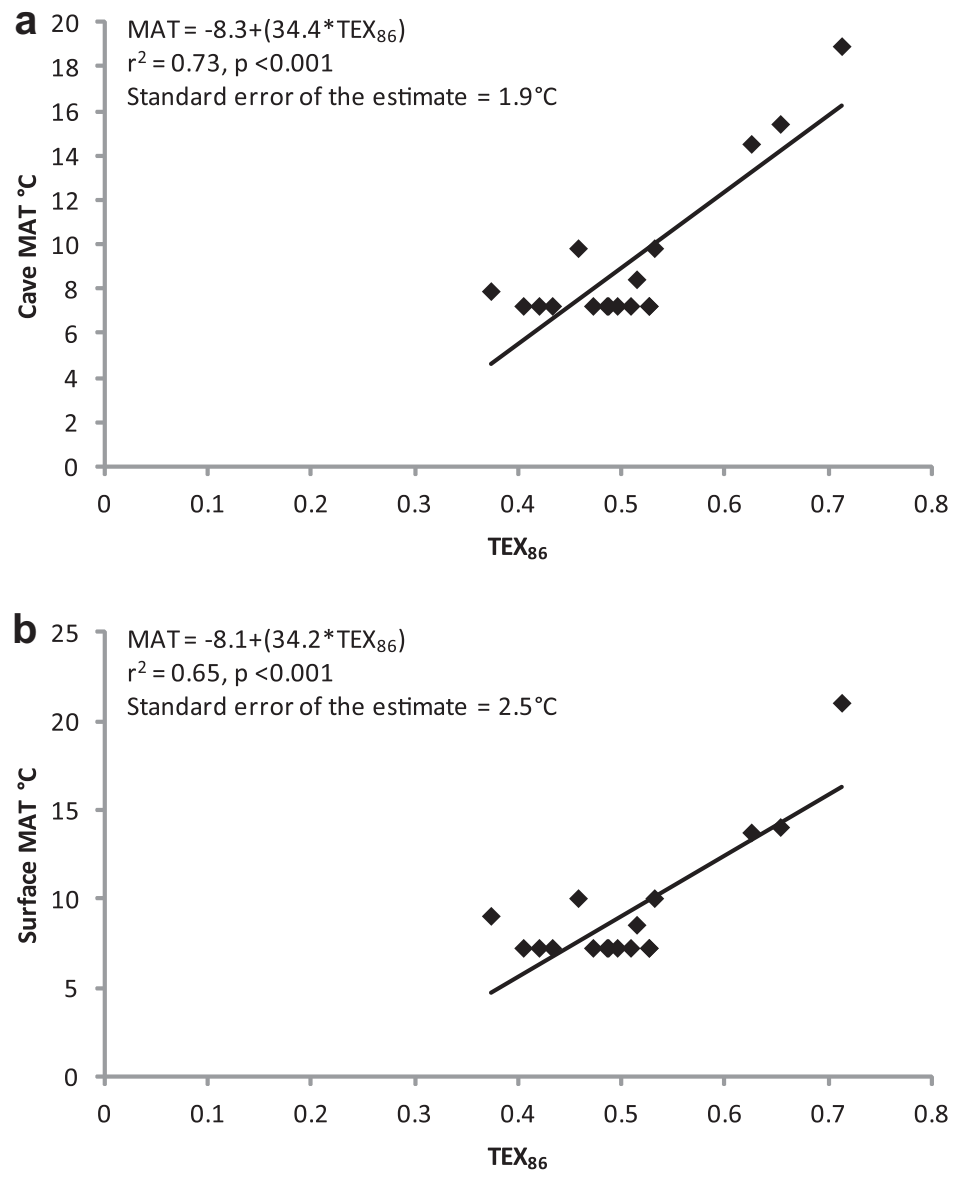

Fig. 11. Scatter plots showing the relationship between surface MAT (a) and cave MAT (b) and TEX ${ }_{86}$ for the reduced dataset for which both cave and surface temperature data are available. 
of the estimate $=2.3^{\circ} \mathrm{C}$ ). A similar exercise rerunning the multi-linear regression for the MBT/CBT proxy $(n=15$, from 7 sites) gives an $r^{2}$ for the cave correlation of 0.56 $\left(p=0.007\right.$; standard error of the estimate $\left.=2.7^{\circ} \mathrm{C}\right)$, and a surface correlation of $r^{2}=0.44(p=0.031$; standard error of the estimate $=3.2^{\circ} \mathrm{C}$ ). The correlations are much less robust than the original calibrations of the full cave and surface temperature data sets. However, in the case of both proxies, the results suggest that the poorer performance of the cave calibrations in the full sample sets may indeed be caused by the reduced size of the available data-set. Given the constraints of the currently available data sets, we consider the full data set correlation with surface MAT to be the most robust and useful calibration available at present, as it is based on the largest number of samples and sites. However, the development of a larger data-set based on internal cave MAT should be a priority for future work in this area, so that the calibrations can be revisited in future and made statistically more robust.

Another issue is the degree of error, not in the GDGT proxies, but in the surface and cave temperature measurements used for the calibration. The cave temperatures are generally the result of direct monitoring projects. However, due to the constraints arising from using a largely archive derived sample set, the surface temperatures have been derived from a range of sources ranging from local monitoring in the direct vicinity of the cave through to published regional weather station measurements. The latter in particular may not be completely representative of the microclimate in the cave or in the soil directly above. Future modern monitoring work could significantly reduce uncertainty in measured MAT and improve our understanding of the limitations of the current calibrations, although such measurements are unlikely to ever be available for all speleothem sites. There is also a degree of error inherent in the use of modern or historical climate measurements in comparison with results from speleothem samples which will be time-averaged over potentially a few hundred years. Due to the amount of calcite required to obtain a measurable organic signal, this error is unavoidable at all but sites with exceptional growth rates. Targeting new sample collection at such sites will help ensure the robustness of the calibration, and the impact of factors such as seasonality.

\section{CONCLUSIONS}

This study has shown that GDGTs are recoverable at measurable levels from speleothem samples from a wide range of environments and climates, and that significant correlations with temperature are observed with both $\mathrm{TEX}_{86}$ and MBT/CBT proxies, allowing us to create the first speleothem based proxy calibrations. The correlation coefficients and standard errors for both proxies compare favourably with the use of GDGT proxies in marine, lacustrine and terrestrial contexts. The unique mixed aquatic/terrestrial environment of caves is probably responsible for the unusual situation of both $\mathrm{TEX}_{86}$ and MBT/CBT based proxies being useable, although the dominance of crenarchaeol in this context suggests that $\mathrm{TEX}_{86}$ is likely to be the most effective proxy in the long-term. The considerable potential shown here now needs to be built on by further work which should be aimed at identifying, and if possible reducing the scatter in the correlation; identifying any conflicting controls on the signal, which may include other climatic factors such as precipitation, as well as variations in the microbial communities, and increasing the calibration sample set, especially to increase the number of samples for which measured cave temperature is available. An increased data set will also enable a reappraisal of the most appropriate GDGT index to use in speleothems, including investigation of new equations developed specifically for the cave context. These advances will help in the development of a strong and robust novel terrestrial palaeotemperature proxy.

\section{ACKNOWLEDGEMENTS}

This work was supported by a Leverhulme Early Career Fellowship to AJB. The Isaac Newton Trust, Cambridge, provided additional financial support. SS thanks the Netherlands Organisation for Scientific Research (NWO) for financial support through a VICI grant. Jort Ossebaar and Ellen Hopmans (NIOZ) are thanked for their assistance in the GDGT analyses. Additional speleothem samples and contextual data were supplied by: Andy Baker (Merc-1, Ach-1), Catherine Jex (Turk-1) and Adam Hartland (PC-1) of the University of Birmingham (now at the University of New South Wales); Pauline Treble (Lab-S2) of ANSTO; John Hellstrom (MD-3 and Net-1) of the University of Melbourne; Russell Drysdale (WM-3 and SC-4) of the University of Newcastle, NSW (now at the University of Melbourne); Janece MacDonald (WM-4) of the University of Newcastle, NSW; and David Dominguez-Villar (Pos-1, EC-1, LBM-S2 and LBM-S3) of the University of Birmingham. Susan and Nicholas White facilitated collection of samples from Buchan and Bats Ridge, and Parks Victoria, Mrs Davies, and the management of Wellington Caves are thanked for permitting necessary site access. Silvia Frisia (University of Newcastle, NSW) provided additional information on the fabric of SC-4, and Helen Green (University of Melbourne) provided $\mathrm{pH}$ measurements for Buchan.

\section{REFERENCES}

Affek H. P., Bar-Matthews M., Ayalon A., Matthews A. and Eiler J. M. (2008) Glacial/interglacial temperature variations in Soreq cave speleothems as recorded by 'clumped isotope' thermometry. Geochim. Cosmochim. Acta 72, 5351-5360.

Asrat A., Baker A., Leng M. J., Gunn J. and Umer M. (2008) Environmental monitoring in the Mechara caves, southeastern Ethiopia: implications for speleothem palaeoclimate studies. Int. J. Speleol. 37, 207-220.

Bechtel A., Smittenberg R. H., Bernasconi S. M. and Schubert C. J. (2010) Distribution of branched and isoprenoid tetraether lipids in an oligotrophic and a eutrophic Swiss lake: insights into sources and GDGT-based proxies. Org. Geochem. 41, 822-832.

Blaga C. I., Reichart G. J., Heiri O. and Sinninghe Damsté J. S. (2009) Tetraether membrane lipid distributions in water column particulate matter and sediments: a study of 47 European lakes along a north-south transect. J. Palaeolimnol. 41, 523-540.

Blaga C. I., Reichart G.-J., Schouten S., Lotter A., Werne J. P., Kosten A., Mazzeo N., Lacerot G. and Sinninghe Damsté J. S. (2010) Branched glycerol dialkyl flycerol tetraethers in lake sediments: can they be used as temperature and $\mathrm{pH}$ proxies? Org. Geochem. 41, 1225-1234. 
Blyth A. J. (2007) Lipid biomarkers in speleothems. Unpublished $\mathrm{Ph}$. D. thesis, Newcastle Univ., UK.

Blyth A. J., Farrimond P. and Jones M. (2006) An optimised method for the extraction and analysis of lipid biomarkers from stalagmites. Org. Geochem. 37, 882-890.

Blyth A. J., Asrat A., Baker A., Gulliver P., Leng M. and Genty D. (2007) A new approach to detecting vegetation and land-use change: high resolution lipid biomarker records in stalagmites. Quaternary Res. 68, 314-324.

Blyth A. J., Watson J. S., Woodhead J. and Hellstrom J. (2010) Organic compounds preserved in a three million year old stalagmite from the Nullarbor Plain, Australia. Chem. Geol. 279, 101-105.

Blyth A. J., Baker A., Thomas L. E. and van Calsteren P. (2011) A 2000-year lipid biomarker record preserved in a stalagmite from northwest Scotland. J. Quaternary Sci. 26, 326-334.

Brochier-Armanet C., Boussau B., Gribaldo S. and Forterre P. (2008) Mesophilic Crenarchaeota: proposal for a third archaeal phylum, the Thaumarchaeota. Nat. Rev. Microbiol. 6, 245-252.

Buckley D. H., Graber J. R. and Schmidt T. M. (1998) Phylogenetic analysis of nonthermophilic members of the kingdom Crenarchaeota and their diversity and abundance in soils. Appl. Environ. Microbiol. 64, 4333-4339.

Castañeda I. S. and Schouten S. (2011) A review of molecular organic proxies for examining modern and ancient lacustrine environments. Quaternary Sci. Rev. 30, 2851-2891.

Daëron M., Guo W., Eiler J., Genty D., Balmart D., Boch R., Drysdale R., Maire R., Wainer K. and Zanchetta G. (2011) ${ }^{13} \mathrm{C}^{18} \mathrm{O}$ clumping in speleothems: observations from natural caves and precipitation experiments. Geochim. Cosmochim. Acta 75, 3303-3317.

Dansgaard W., Johnsen S. J., Clusen H. B., Dahl-Jensen D., Gundestrup N. S., Hammer C. U., Hvidberg C. S., Steffensen J. P., Sveinbjörnsdottir A. E., Jouzel J. and Bond G. (1993) Evidence for general instability of past climate from a 250-kyr ice-core record. Nature 364, 218-220.

De La Torre J. R., Walker C. B., Ingalls A. E., Könneke M. and Stahl D. A. (2008) Cultivation of a thermophilic ammonia oxidising archaeon synthesising Crenarchaeol. Environ. Microbiol. 10, 810-818.

Delong E. F. (1992) Archaea in coastal marine environments. Proc. Natl. Acad. Sci. USA 89, 5685-5689.

Elderfield H. and Ganssen G. (2000) Past temperature and $\delta^{18} \mathrm{O}$ of surface ocean waters inferred from foraminiferal $\mathrm{Mg} / \mathrm{Ca}$ ratios. Nature 405, 442-445.

Fuhrman J. A., McCallum K. and Davis A. A. (1992) Novel major archaebacterial group from marine plankton. Nature 356, 148149.

Fuller L., Baker A., Fairchild I. J., Spötl C., Marca-Bell A., Rowe P. and Dennis P. F. (2008) Isotope hydrology of dripwaters in a Scottish cave and implications for stalagmite palaeoclimate research. Hydrol. Earth Syst. Sci. 12, 1065-1074.

Gascoyne M., Schwarcz H. P. and Ford D. C. (1980) A palaeotemperature record for the mid-Wisconsin in Vancouver Island. Nature 285, 474-476.

Gattinger A., Günthner A., Schloter M. and Munch J. C. (2003) Characterisation of Archaea in soils by polar lipids analysis. Acta Biotechnol. 23, 21-28.

Genty D., Plagnes V., Causse C., Cattani O., Stievenard M., Falourd S., Blamart D., Ouahdi R. and Van-Exter S. (2002) Fossil water in large stalagmite voids as a tool for paleoprecipitation stable isotope composition reconstitution and palaeotemperature calculation. Chem. Geol. 184, 83-95.

Gliozzi A., Paoli G., DeRosa M. and Gambacorta A. (1983) Effect of isoprenoid cyclization on the transition temperature of lipids in thermophilic archaeabacteria. Biochim. Biophys. Acta 735, 234-242.

Gonzalez J. M., Portillo M. C. and Saiz-Jimenez C. (2006) Metabolically active Crenarchaeota in Altamira Cave. Naturwissenschaften 93, 42-45.

Hopmans E. C., Weijers J. W. H., Schefuß E., Herfort L., Sinninghe Damsté J. S. and Schouten S. (2004) A novel proxy for terrestrial organic matter in sediments based on branched and isoprenoid tetraether lipids. Earth Planet. Sci. Lett. 224, 107-116.

Johnsen S. J., Dahl-Jensen D., Gundestrup N., Steffensen J. P., Clausen H. B., Miller H., Masson-Delmotte V., Sveinbjörnsdottir A. E. and White J. (2001) Oxygen isotope and palaeotemperature records from six Greenland ice-core stations: Camp Century, Dye-3, GRIP, GISP2, Renland and NorthGRIP. J. Quaternary Sci. 16, 299-307.

Kim J.-H., Schouten S., Hopmans E. C., Donner B. and Sinninghe Damsté J. S. (2008) Global sediment core-top calibration of the TEX $_{86}$ paleothermometer in the ocean. Geochim. Cosmochim. Acta 72, 1154-1173.

Kim J.-H., van der Meer J., Schouten S., Helmke P., Wilmott V., Sangiorgi F., Koç N., Hopmans E. C. and Sinninghe Damsté J. (2010) New indices and calibrations derived from the distribution of crenarcheal isoprenoid tetraether lipids: implications for past sea surface temperature reconstructions. Geochim. Cosmochim. Acta 74, 4639-4654.

Leininger S., Urich T., Schloter M., Schwark L., Qi J., Nicol G. W., Prosser J. I., Schuster S. C. and Schleper C. (2006) Archaea predominate among ammonia-oxidizing prokaryotes in soils. Nature 442, 806-809.

Mangini A., Spötl C. and Verdes P. (2005) Reconstruction of temperature in the Central Alps during the past $2000 \mathrm{yr}$ from a $\delta^{18} \mathrm{O}$ stalagmite record. Earth Planet. Sci. Lett. 235, 741-751.

McDermott F. (2004) Palaeo-climate reconstruction from stable isotope variations in speleothems: a review. Quaternary Sci. Rev. 23, 901-918.

Meckler A. N., Adkins J. F., Eiler J. M. and Cobb K. M. (2009) Constraints from clumped isotope analyses of a stalagmite on maximum tropical temperature change through the late Pleistocene. Geochim. Cosmochim. Acta 73(Suppl.), A863.

Müller P. J., Kirst G., Ruhland G., von Storch I. and Rosell-Melé A. (1998) Calibration of the alkenone palaeotemperature index $\mathrm{U}_{37}{ }^{\mathrm{K}^{\prime}}$ based on core-tops from the eastern South Atlantic and the global ocean $\left(60^{\circ} \mathrm{N}-60^{\circ} \mathrm{S}\right)$. Geochim. Cosmochim. Acta $\mathbf{6 2}$, $1757-1772$.

Ochsenreiter T., Selezi D., Quaiser A., Bonch-Osmolovskaya L. and Schleper C. (2003) Diversity and abundance of Crenarchaeota in terrestrial habitats studied by 16S RNA surveys and real time PCR. Environ. Microbiol. 5, 787-797.

Pearson E. J., Juggins S., Talbot H. M., Weckström J., Rosén P., Ryves D. B., Roberts S. J. and Schmidt R. (2011) A lacustrine GDGT-temperature calibration from the Scandinavian Arctic to Antarctic: renewed potential for the application of GDGTpalaeothermometry in lakes. Geochim. Cosmochim. Acta 75, 6225-6238.

Peterse F., van der Meer J., Schouten S., Weijers J. W. H., Fierer N., Jackson R. B., Kim J.-K. and Sinninghe Damsté J. S. (2012) Revised calibration of the MBT-CBT paleotemperature proxy based on branched tetraether membrane lipids in surface soils. Geochim. Cosmochim. Acta 96, 215-229.

Petit J. R., Jouzel J., Raynaud D., Barkov N. I., Barnola J.-M., Basile I., Bender M., Chappellaz J., Davis M., Delaygue G., Delmotte M., Kotlyakov V. M., Legrand M., Lipenkov V. Y., Lorius C., Pépin L., Ritz C., Saltzman E. and Stievenard M. (1999) Climate and atmospheric history of the past 
420,000 years from the Vostok ice core, Antartica. Nature 399, 429-436.

Powers L. A., Werne J. P., Johnson T. C., Hopmans E. C., Sinninghe Damsté J. S. and Schouten S. (2004) Crenarchaeotal membrane lipids in lake sediments: a new palaeotemperature proxy for continental palaeoclimate reconstruction. Geology 32, 613-616.

Powers L. A., Werne J. P., Vanderwoude A. J., Sinninghe Damsté J. S., Hopmans E. C. and Schouten S. (2010) Applicability and calibration of the $\mathrm{TEX}_{86}$ palaeothermometer in lakes. Org. Geochem. 41, 404-413.

Scheidegger Y., Baur H., Brennwald M. S., Fleitmann D., Wieler R. and Kipfer R. (2010) Accurate analysis of noble gas concentrations in small water samples and its application to fluid inclusions in stalagmites. Chem. Geol. 272, 31-39.

Schouten S., Hopmans E. C., Pancost R. D. and Sinninghe Damsté J. S. (2000) Widespread occurrence of structurally diverse tetraether membrane lipids: evidence for the ubiquitous presence of low temperature relatives of hyperthermophiles. Proc. Natl. Acad. Sci. USA 97, 14421-14426.

Schouten S., Hopmans E. C., Schefuß E. and Sinnginghe Damsté J. S. (2002) Distributional variations in marine crenarchaeotal membrane lipids: a new tool for reconstructing ancient sea water temperatures? Earth Planet. Sci. Lett. 204, 265-274.

Schouten S., Huguet C., Hopmans E. C. and Sinninghe Damsté J. S. (2007) Improved analytical methodology of the $\mathrm{TEX}_{86}$ paleothermometry by high performance liquid chromatography/atmospheric pressure chemical ionization-mass spectrometry. Anal. Chem. 79, 2940-2944.

Schouten S., Eldrett J., Greenwood D. R., Harding I., Baas M. and Sinninghe Damsté J. S. (2008) Onset of long-term cooling of Greenland near the Eocene-Oligocene boundary as revealed by branched tetraether lipids. Geology 36, 147-150.

Schouten S., Hopmans E. C. and Sinninghe Damsté J. S. (2013) The organic geochemistry of glycerol dialkyl glycerol tetraether lipids: a review. Org. Geochem. 54, 19-61.

Schwarcz H. P. and Harmon R. S. (1976) Stable isotope studies of fluid inclusions in speleothems and their palaeoclimatic significance. Geochim. Cosmochim. Acta 40, 657-665.

Sinninghe Damsté J. S., Schouten S., Hopmans E. C., Van Duin A. C. T. and Geenevasen J. A. J. (2002) Crenarchaeol: the characteristic core glycerol dibiphytanyl glycerol tetraether membrane lipid of cosmopolitan pelagic Crenarchaeota. $J$. Lipid Res. 43, 1641-1651.

Spang A., Hatzenpichler R., Brochier-Armanet C., Rattei T., Tischler P., Spieck E., Streit W., Stahl D. A., Wagner M. and Schleper C. (2010) Distinct gene set in two different lineages of ammonia-oxidizing archaea supports the phylum Thaumarchaeota. Trends Microbiol. 554, 331-340.
Sun Q., Chu G., Liu M., Li S., Ling Y., Wang X., Shi L., Jia G. and Lü H. (2011) Distributions and temperature dependence of branched glycerol dialkyl glycerol tetraethers in recent lacustrine sediments from China and Nepal. J. Geophys. Res. 116. http://dx.doi.org/10.1029/2010JG001365.

Talma A. S. and Vogel J. C. (1992) Late Quaternary palaeotemperatures derived from a speleothem from Cango Caves, Cape Province, South Africa. Quaternary Res. 37, 203-213.

Tierney J. E. and Russell J. M. (2009) Distributions of branched GDGTs in a tropical lake system: implications for lacustrine application of the MBT/CBT palaeoproxy. Org. Geochem. 40, 1032-1036.

Tierney J. E., Russell J. M., Eggermont H., Hopmans E. C., Verschuren D. and Sinninghe Damsté J. S. (2010) Environmental controls on branched tetraether lipid distributions in tropical East African lake sediments. Geochim. Cosmochim. Acta 74, 4902-4918.

Van Breukelen M. R., Vonhof H. B., Hellstrom J. C., Wester W. C. G. and Kroon D. (2008) Fossil dripwater in stalagmites reveals Holocene temperature and rainfall variation in Amazonia. Earth Planet. Sci. Lett. 275, 54-60.

Weijers J. W. H., Schouten S., Spaargaren O. C. and Sininghe Damsté J. S. (2006) Occurrence and distribution of tetraether membrane lipids in soils: implications for the use of the $\mathrm{TEX}_{86}$ proxy and the BIT index. Org. Geochem. 37, 1680-1693.

Weijers J. W. H., Schouten S., van den Donker J. C., Hopmans E. C. and Sinninghe Damsté (2007a) Environmental controls on the bacterial tetraether membrane lipid distribution in soils. Geochim. Cosmochim. Acta 71, 703-713.

Weijers J. W. H., Schouten S., Sluijs A., Brinkhuis H. and Sinninghe Damsté J. S. (2007b) Warm arctic continents during the Palaeocene-Eocene thermal maximum. Earth Planet. Sci. Lett. 261, 230-238.

Wuchter C., Schouten S., Coolen M. J. L. and Sinninghe Damsté J. S. (2004) Temperature-dependent variation in the distribution of tetraether membrane lipids of marine Crenarchaeota: implications for $\mathrm{TEX}_{86}$ palaeothermometry. Palaeoceanography 19, PA4028. http://dx.doi.org/10.1029/2004PA001041.

Xie S., Yi Y., Huang J., Hu C., Cai Y., Collins M. and Baker A. (2003) Lipid distribution in a subtropical southern China stalagmite as a record of soil ecosystem response to palaeoclimate change. Quaternary Res. 60, 340-347.

Yang H., Ding W., Zhang C. L., Wu X., Ma X., He G., Huang J. and Xie S. (2011) Occurrence of tetraether lipids in stalagmites: implications for sources and GDGT-based proxies. Org. Geochem. 42, 108-115. 